\title{
The Central Role of Credit Crunches in Recent Financial History
}

THIS PAPER addresses, from an unusual perspective, some key aspects of the interactions between financial markets and the real economy in the United States over the past thirty years. The emphasis is on the upper cyclical turning points in general business. The theme is to show how the credit bottlenecks that accompanied and in fact triggered these turning points prompted the removal of the confining constraints and thereby shaped the cycles and inflation of the future. The vantage point is that of a. trained economist who has spent nearly all this time in a ringside seat in the New York financial community - the first dozen years in the Federal Reserve Bank of New York and the remainder in commercial and investment banking. Perhaps some of the observations offered in this paper may eventually be useful in a more formal setting.

The key observation, controversial though it may be, is that the propensity to spend (that is, the demand for nominal GNP) and therefore the demands for credit are inelastic (or at times even perversely positive) with respect to the general level of interest rates. The growth of credit is therefore essentially supply-determined-if not always, then at least at those times that are cyclically important; and if not at every level of rate,

The author acknowledges the research assistance of Zwenyslava A. Goy, Thomas C. Hier, and Elizabeth $\mathrm{H}$. Willett and the help of members of the Brookings panel, which prompted a number of improvements in the paper. He also thanks Nellie Hirshman for exceptional typing help. 
then at least at any level that the community on the basis of its experience has regarded as remotely conceivable.

In particular, this has meant that cyclically significant retardations or reductions in credit and aggregate demand occur only when there is an interruption in the supply of credit-a "credit crunch." Such interruptions may be prompted, intentionally or accidentally, by the destruction of lenders' incentives through regulatory rigidities, such as ceilings on the interest rate, or the emergence of serious default problems in major institutions or markets.

Following such episodes, however, the authorities (to avoid the consequent recessions) and the private markets (to protect future earnings) have deliberately reshaped the financial structure so as to prevent the recurrence of that particular form of credit supply interruption. As a result, subsequent cyclical increases in credit, interest rates, inflation, and general business have been able to continue longer and to reach greater extremes. Ironically, because each appearance of unprecedently high nominal interest rates has been viewed by the authorities and the marketplace as foretelling recession (and lower rates), at such times both monetary policies and lenders' attitudes have taken on a more expansionary bias. ${ }^{1}$

Between credit crunches the changing expectations of financial market participants play an important part in determining the rate of growth of credit and nominal GNP. These expectations, however, tend to have large and mercurial short-run swings, are often inconsistent even within particular enterprises, and appear to be influenced more by extreme and memorable events than by slow-moving processes. Thus the desired stocks of financial assets change frequently and sizably, and in directions that may make little sense to the outside (and because of random components, often the inside) observer. But because adjustment of actual to desired financial stocks can be virtually instantaneous, especially as compared with the glacial pace of the corresponding adjustments in human and physical capital mediated by changes in financial asset preference, financial behavior becomes a routinely dominant force in business fluctuations.

From this standpoint, the institutional changes of the last decade to free financial markets from kinks that caused crunches have also greatly

1. Because of the major structural changes in finance between most successive cycles, the behavior of financial data, including monetary aggregates, also is likely to have different implications from cycle to cycle. 
intensified the propensity of the economy to excessive credit expansion and inflation. Innovations such as the deregulation of interest rates, the spread of loans with variable rates, the shift to an $\mathbf{M}_{1}$-oriented monetary policy, and the establishment of financial futures markets have in effect removed most financial "speed limits" on the assumption that market forces will generate more rational and flexible limits of their own. However, William Bagehot's terse admonition that "money will not manage itself" is only one of a long series of observations, traceable through the millenia of human history, that recognizes the narcotic attraction of borrowing and the related phenomena of gambling and asset-price speculation. At present, when the welfare state is seen as providing "catastrophe insurance" to businesses and individuals, and people are having fewer children (which, having lost their former status as capital goods, are apparently also becoming too expensive as consumer goods), the public's inclination to accumulate capital and to avoid risk should be diminishing. Thus one may regard the liberalization of financial regulation and an increase in gambling as a logical expression of the "now" generation.

This paper presents a compressed history of the past thirty years from this point of view, pausing along the way to highlight the genesis of significant regulatory and institutional patterns that have grown to major current importance. Figure 1 summarizes the behavior of money and credit flows and interest rates over this period. A concluding section deals directly with the subject of expectations. Admittedly such a selective procedure involves a deliberate kind of distortion because many other important developments outside and even within the financial sector will not be addressed.

\section{The 1950s—From Liquifying Bond Portfolios to Disintermediation}

The United States emerged from World War II, it will be recalled, with a structure of low nominal and real interest rates rigidly controlled to minimize the carrying cost of the federal debt. The growth and allocation of private credit demand was regulated by a variety of official priorities. During the Korean War, mandatory as well as voluntary credit controls were reintroduced, limiting consumer, mortgage, and certain types of business credit while giving military industry priority access. Both demand and supply of credit were also restrained by recollection of the 
Figure 1. Fluctuations in Bank Credit, Money Supply, and Interest Rates, 1952:2-1980: $2^{\mathrm{a}}$
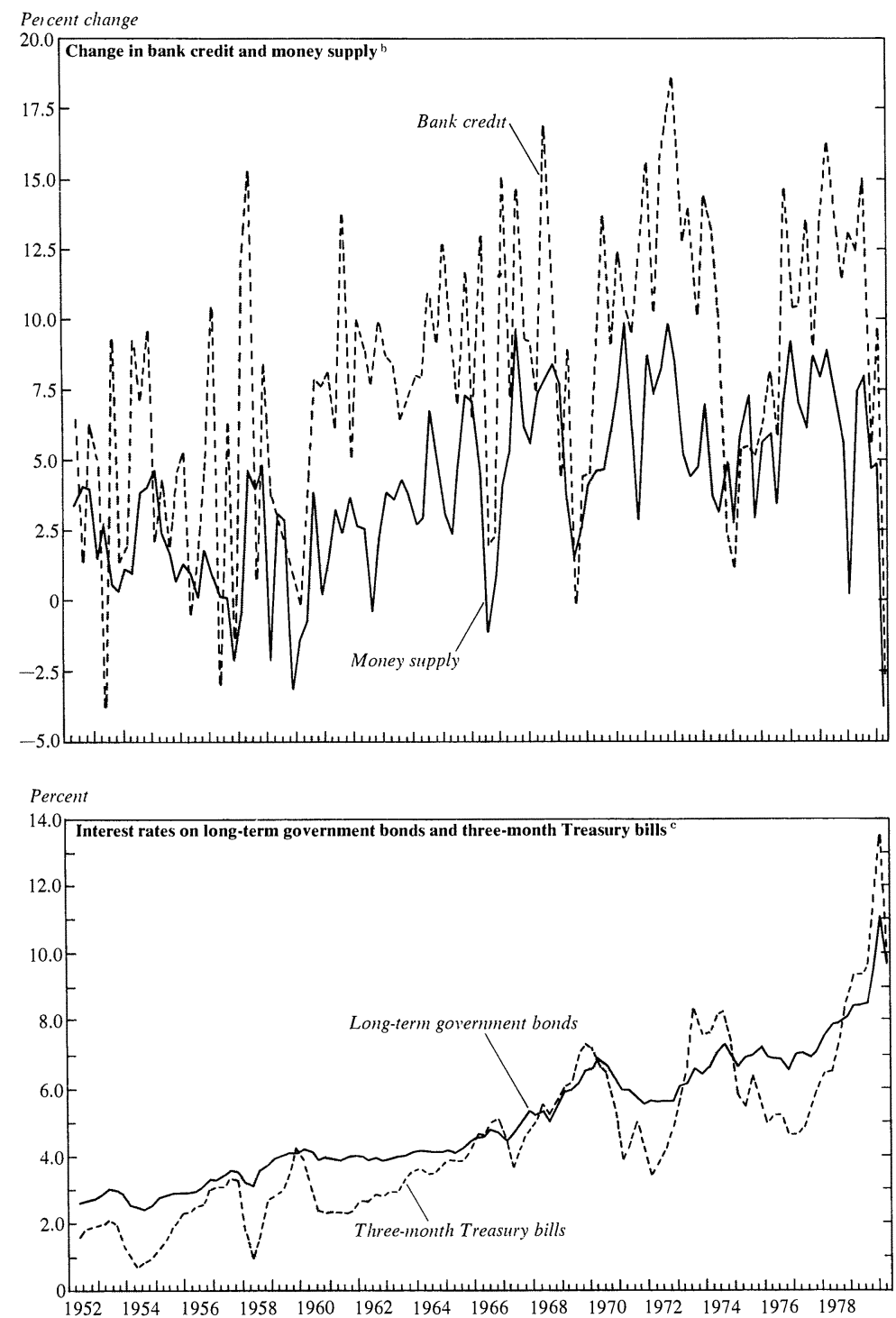

Source: Board of Governors of the Federal Reserve System.

a. Shaded areas indicate periods of recession.

b. Data are quarterly changes at seasonally adjusted annual rates. The series for money shows $\mathbf{M}_{1}$ until 1958:4 and $M_{1 A}$ since then. Data for bank credit are from flow-of-funds accounts. Seasonally adjusted quarterly flows were cumulated starting from the 1951 stock data to yield the adjusted series for the stock. c. Not seasonally adjusted; average market yield for the quarter. 
Great Depression that preceded World War II and that experts feared might be repeated once the stimulus of military demand (and low interest rates) was withdrawn.

Financial institutions had little discretion over the size and composition of their sources of funds. What is today termed liability management was largely out of the question. Depositary institutions were effectively prohibited from deposit-rate competition with one another by various regulatory rate ceilings. With branching also sharply restricted, the lending resources of depositaries were limited essentially to the incremental deposits that they could attract from local customers and to whatever securities-essentially U.S. Treasury obligations accumulated during the war-they were willing and able to sell in the open market. The prevailing rate of interest was palpably below free-market levels, but existing rules to preserve the situation were difficult for the public and financial institutions to circumvent.

In the early postwar years, a number of measures, including the celebrated 1951 "accord" between the U.S. Department of the Treasury and the Federal Reserve, loosened the "peg" on government security prices in the effort to inhibit the propensity of financial institutions and potentially also individuals (although these latter remained quite "well behaved") to unload securities on the Federal Reserve and thereby cause an undue expansion of bank reserves. Capital losses in government security prices were still taken seriously by many institutions. Although they were no longer required to write down capital for unrealized losses, many bankers remembered all too well how bank examiners during the depression marked down assets and capital and thereby forced the closing of otherwise solvent banks. Given these and the Treasury's concerns, the authorities allowed only infrequent declines in bond prices and provided various cushions to soften the blows. In the second half of 1952, following the ebbing of the boom related to the Korean War, economic expansion and inflation reaccelerated sharply. By the then-prevailing standards, Federal Reserve policy was tightened, but it was questioned whether the tightening would be effective if the authorities remained constrained by bondmarket considerations.

The pivotal event that severed the knot was the fledgling Republican administration's decision to issue in March 1953 a new thirty-year obligation that more genuinely reflected the underlying market conditions-the $3 \frac{114}{4}$ percent bonds due 1983. Prices of outstanding long-term bonds, which 
mostly carried $2^{1 / 2}$ percent coupons, fell correspondingly. It is difficult to recapture today the shock felt in the financial community at this startling devaluation of a major part of its assets. It was an environment in which many economists warned that even the smallest rises in interest rates might cause a depression and in which the most respected economic advisers of the banks had vouchsafed that the basic $2 \frac{1}{2}$ percent government bond rate would quite literally never go up. On a rough calculation, the drop in bond prices in early 1953 would have reduced total commercial bank capital by 5 percent had their securities holdings been "marked to the market." Bank credit became scarce. Within just a few weeks, observers could take for granted that a recession was now unavoidable; it began shortly after midyear.

The shock did not last long. Quickly it became evident that the public's confidence in the banks and other financial intermediaries had in no way been undermined. The institutions learned that, within generous limits, they had little to fear even from losses actually realized through market sales and in fact deducted from their capital. The so-called lock-in effect, which some had viewed as the key linkage by which rising interest rates restrained credit expansion, largely disappeared. The process was accelerated by a quick turn toward easing by the Federal Reserve which, together with the recession, replaced capital losses on recently acquired bonds with gains. Banks were helped to appreciate the usefulness of bond price fluctuations by tax provisions (not phased out until the 1970s) that allowed net security losses in any year to be deducted from operating profits, while net gains were taxed at only the capital gains rate. Like the pulling of a tooth, the credit crisis of spring 1953, though painful, was quickly forgotten by the patient-but not by the Treasury, which ventured only three more long-term bond issues over the next ten years and these only when Federal Reserve policy was aggressively expansionary. This, then, was the first in a long series of encounters to be recited here in which, each time, the authorities were more alarmed than the public by the consequences of their actions.

The nation's banking system thus entered the 1954-57 business expansion still shackled in its ability to compete for deposits, but freed of its fear of selling government securities. Indeed, lending institutions now became eager to replace these securities with private loans bearing higher yields. These were the years in which, abruptly, the typical automobile installment loan term lengthened from two years to three (at lower down 
payments) and mortgage terms for a while eased to the extent that in parts of the country no-down-payment and "no-no-down-payment" (closing costs included in the loan) mortgages were advertised. The question was how low liquidity considerations would permit government security portfolios to sink. (Keep in mind that banks had no important way to borrow in the money market.) As usual, the prognostications of recession set in prematurely, particularly as business borrowing to finance a plant and equipment boom began to crowd out mortgage and automobile credit in 1956. Banks reduced their government securities holdings about 20 percent between the beginning and end of the expansion. Interest rates rose, but with the prime loan rate peaking at $41 / 2$ percent (and the quarterly GNP deflator at 4.7 percent) it seems unlikely that price rationing through higher interest rates played any important role in curbing demand. On the other hand, as the expansion drew toward its close in August 1957, there were many reports of nonprice rationing of credit. Financial pressure was intensified by "unexpected curtailment in defense payments and changes in procurement policies . . . to avoid exceeding budget estimates and the debt ceiling, [which] had an unsettling effect on business in early autumn." In other words, the federal government for a time stopped paying some of its bills. ${ }^{2}$ Just when credit was becoming tight, many firms were forced into unplanned borrowings from their banks. Although an acute sense of credit stringency developed, no terribly threatening shock to the financial system occurred, so that the 1957 crest in business might be labeled the last "gentle" upper cyclical turning point.

With no crisis having intervened, the next cycle was in effect a replay. Financial institutions soon considered their liquidity replenished (as in 1953-54, the Federal Reserve moved to "aggressive ease," with Treasury bill rates dropping well below 1 percent), and the whole process began to repeat, faster. The economy appeared to be more inflation-prone, and the Federal Reserve more willing to exercise restraint. It took only five quarters, compared with ten in the previous cycle, for the government securities holdings of banks to shrink about 20 percent. In more modern fashion, interest rates rose more sharply and for the first time provoked a degree of disintermediation. Large commercial banks had begun to develop a time-deposit market, but they lost substantially all interest-sensip. 5 .

2. Board of Governors of the Federal Reserve System, 44th Annual Report, 1957,
5. 
tive balances as Treasury bill rates rose above the 3 percent Regulation $\mathrm{Q}$ ceiling on time-deposit interest rates. More important, the Treasury's issuance in October 1959 of the "Magic fives" (five-year notes carrying a 5 percent coupon) prompted the startling spectacle of lines of people around banking institutions withdrawing deposits and around the Federal Reserve Banks subscribing for the new notes.

These developments triggered a sharp increase in desired liquidity and retrenchment of credit offerings on the part of the financial sector. The consequent onset of recession in the economy was delayed to April 1960 only by the anticipation and realization of the massive rebound in steel buying and output that was to follow the July-November 1959 strike, which was not finally settled until January 1960 .

Here, then, was a case in which severe credit stringency had developed not because any general rise in interest rates deterred borrowers, but because particular rates had been forced to remain in place by regulation while others rose. As a result, important financial institutions and dependent customers were put in jeopardy of insolvency. Who knows how much higher interest rates might have escalated even as far back as 1959 if banks and thrift institutions had been allowed to leapfrog their deposit interest rates above Treasury yields. Few such concerns then troubled either the authorities or the public. The moral drawn from the experience was a quite different one: disintermediation leads to recessions. As in 1953, the authorities had frightened themselves. They acquired a deepseated fear of disintermediation-and market participants knew it.

\section{The 1960s—Certificates of Deposit, Eurodollars, and Liability Management}

For the large commercial banks the continuing restrictions on their ability to bid for deposits were becoming onerous. The banks were having difficulty keeping up with their major clients. As these clients evolved into national and international concerns with greatly expanded credit requirements, they had to turn to an ever widening circle of banking sources because the growth of their "lead" banks remained essentially dependent on narrow local deposit markets. It was in response to such pressures that in early 1962 the negotiable certificate of deposit (CD) burst on the scene, spearheading a rapid and total transformation of finan- 
cial practice. It is little wonder that several econometric studies concerned with the relations among financial aggregates, inflation, and interest rates detect—or are clouded by - a break of continuity in the early 1960s.

The new instrument-which from the standpoint of the buyers was essentially a high-quality, more flexible, and higher yielding type of Treasury bill-suddenly enabled well-known banks to bid for deposits all over the world. At a price, funds would always be available. If a loan or security was available at a good rate anywhere in the world, it was profitable to acquire it, and to do so promptly before it was snapped up by another of what justly came to be called the universal banks.

What were the perceived risks? Were they credit defaults? These had been minimal for decades; now that governments had demonstrated their ability and political determination to prevent severe recessions, they were likely to be even fewer. Were they adverse rate movements? Short-term rates (the cost of $\mathrm{CD}$ money) had almost always been less, and usually by a large margin, than the corporate bond yields to which the prime-loan rate was informally pegged. The rate of return on consumer loans, mortgages, and tax-exempt bonds was of course well above the prime rate. The only conceivable danger was that as in 1959 the ceilings on the Regulation $\mathrm{Q}$ time-deposit interest rate might again become binding, but this contingency seemed remote at a time when the authorities had their hands full trying, for international reasons, to keep the bill rate from falling below $2 \frac{1}{2}$ percent; in 1961, it may be recalled, the "bills only" policy in open-market operations was abandoned for this very reason. Indeed, the ceilings may have been viewed positively, as firm assurance that the cost of $\mathrm{CD}$ funds could never exceed the revenues from the assets in which they were invested. The chief risks were posed to banks unable or unprepared to join the rush to expansion-both their deposit and their loan customers would be competed away.

Confirming that credit growth had all along been held in check mainly by institutional rigidities, the new approach revealed an enormous pentup credit demand and supply. Over the four years beginning early 1962, bank holdings of business-type loans, consumer credit, and mortgages grew at an annual rate of over 13 percent, and holdings of municipal bonds at a 16 percent rate, far in excess of the 7 percent growth rate in nominal GNP. Yet during the same period, indeed for over five years from August 1960 to December 1965 , the prime rate remained unchanged at $4 \frac{1}{2}$ percent. It was presumably the expansionary force of the enlarged supply of 
credit that enabled a none-too-robust economy to plough through, without recession, the shocks of the Pittsburgh-Washington steel-price confrontation and the stock market crash of spring 1962.

The banks had always served as lenders of last resort to the rest of the financial community, while the Federal Reserve, although disciplining the use of the discount window, acted as lender of last resort to the banks. Both relations were profoundly altered by the introduction of CDs. Compared to other financial institutions, the role of the banks was greatly enlarged. It now made sense for banks to open much larger credit lines for other lenders-thrift institutions, insurance companies, finance companies-to finance these lenders in the acquisition of such loans as the banks themselves were not yet able or anxious to make. Although these other institutions lacked the potentially infinite borrowing power bestowed by CDs, they could utilize it indirectly through the banks. In their competitive zeal the banks also nurtured the epidemic growth of the commercial paper market, even though their generosity in granting the securing credit lines on which that market then depended came at the expense of their own loan business. ${ }^{3}$

The relation of the large banks to the Federal Reserve was altered in that the large banks now perceived CD borrowing rather than discountwindow borrowing as their credit recourse of last resort. Unless the authorities were willing to apply the rude club of rate ceilings, CD borrowing was much more difficult to discipline than the discount window. As this became understood, the banks increasingly took control of the lender-of-last-resort function, to the extent that in recent times it has not been far from the truth to regard the Federal Reserve Banks as branches of the large commercial banks. But that is getting ahead of the story. ${ }^{4}$

Every year from 1962 to 1964, an increasingly reluctant Federal Re-

3. As the years pass, backup bank lines are playing a declining role in the commercial paper market, and the market may eventually dispense with them. This would be somewhat analogous to the evolution of the Eurodollar market, which might never have been created if it were not for the Regulation Q ceilings in the United States, but which once entrenched was completely viable even after the ceilings were abolished.

4. This is what Hyman P. Minsky refers to as monetization of private liabilities. The thrust of this paper is very much in the spirit of his work, which teaches that the U.S. economy is tending toward ever greater "financial fragility." See, for example, his John Maynard Keynes (Columbia University Press, 1975), particularly chapters 2 through 4, or "A Theory of Systemic Fragility" in Edward I. Altman and Arnold W. Sametz, eds., Financial Crisis: Institutions and Markets in a Fragile Environment (Wiley, 1977), pp. 138-52. 
serve Board allowed one increase in the Regulation $\mathrm{Q}$ ceilings for CDs. Repeatedly in the nick of time, the authorities raised the ceilings (although sometimes in a manner that created a term structure of CD rates virtually guaranteeing holders a "riding-the-yield-curve" profit and thus actually increasing the demand). In late 1965, in a "showdown" with the banks, the Federal Reserve again blinked first and lifted the rate ceiling for all CD maturities to $5 \frac{1}{2}$ percent. As banks pressed CDs on the market, this meant that rates on Treasury bills and other federal agency short-term securities were, as in 1959, pulled up to levels that threatened disintermediation of thrift institution accounts on which the rate ceilings had remained, since 1962 , at 4 percent. With the inflationary pressures in the economy mounting (largely because of the intensification of the Vietnam War), the Federal Reserve saw itself with a "Hobson's choice." If the CD ceilings were raised further, the thrift institutions would be rapidly disintermediated to the particular detriment of the housing industry; if the ceilings were kept locked in place, the commercial banks, too, would suffer the burden of withdrawals as the public moved its funds from deposits into short-term federal obligations.

The bankers were not worried. The Federal Reserve had always backed down before. From today's longer and sadder perspective, however, it is not surprising that the decision went in favor of the housing industry, especially when, then much as now, a decline in housing construction was widely viewed as a certain trigger to a general recession. This time the $\mathrm{CD}$ rate ceiling was held in place.

The outcome was the notorious "credit crunch" of August-September 1966. (It was then, I believe, that the label "crunch" was first used.) Banks that relied almost entirely on liability management faced the apparent inevitability of massive distress sales of long-term assets into a paralyzed marketplace. Lending to all but the most established and necessitous customers was halted abruptly. Chief executives of leading banks reportedly were humbled to the point of pleading with their counterparts in industry to renew their CDs. Soon the gravity of the situation penetrated to an initially incredulous Federal Reserve. A fist-in-glove letter was issued in effect inviting to the discount window those banks that "behaved" by refraining both from selling securities and from making new business loans. ${ }^{5}$ Other banks, it was implied, would be cut off. Publication of the letter laid to rest the very lively fears that major banks might have

5. The letter was released to the public on September 1, 1966. See the Federal Reserve Bulletin, vol. 52 (September 1966), pp. 1338-39. 
to close their doors. Nevertheless, the double-edged impact of that letter came too late from the standpoint of official intentions to forestall the decline in output and the minirecession that promptly arrived before yearend.

During this experience, corporate bond yields and the prime rate briefly reached the then unheard of level of 6 percent. But there was nothing in the data or in the conversations of the period to suggest that the higher level of nominal interest rates had played any significant role in limiting the quantity of credit demanded, obtained, or spent.

Although the duration of the crunch was short and the adverse cyclical consequences mild, the experience prompted many of the participants to far-reaching conclusions and responses. The Federal Reserve appeared particularly startled and shaken by the brush with apparent disaster, as shown by a long-lasting series of private and public reassurances that no such crisis would ever be permitted to recur. In the short run, the policy rudder was tilted sharply toward ease, pushing interest rates below the disintermediation thresholds. The campaign for fiscal discipline as a substitute for monetary discipline was intensified. Most important, however, was the impetus given to the search for alternatives to flash points such as rate ceilings that cornered the Federal Reserve in stark yes-or-no situations. The circumstances were ripened for a shift of policy focus to the monetary aggregates.

These changes of official attitude did not go unnoticed in the financial community. Once again, some of the banks with the most brazen expansionary bias had turned out to be the ultimate winners, no matter how anxious the moments they might have experienced along the way. Under the pressures of the moment, some bankers had discovered the open door to the borrowing of funds in the unregulated Eurodollar market. They prepared the groundwork for more active use of this source, which greatly mitigated the pressures the next time the $\mathrm{CD}$ rate ceilings became seriously binding in early 1969 .

The crunch also spurred a widespread move toward formalizing in a legally obligating manner the hitherto largely informal credit-line arrangements prevailing between banks and their business customers. Both parties wanted to be protected from future "antilending" injunctions such as that contained in the Federal Reserve's letter of September 1966. Corporations wanted and were willing to pay for legally binding credit lines. Bankers believed that the authorities could not in the future place them 
in a position in which they would have to dishonor such agreements. In effect, they were trying to create still more private instruments with monetary properties. Ever since, the growth of this invisible money supply has rendered suspect policy as well as scholarly conclusions based on monetary aggregate data. Unused bank-credit commitments currently slightly exceed the total quantity of demand deposits included in measures of the money stock.

Unused commitments are in fact more immediately spendable than compensating balances (which are included in $\mathbf{M}_{1}$ ). They are closely analogous to $\mathrm{M}_{1 \mathrm{~A}}$ (demand deposits and currency): the owner incurs a cost of holding (the fee), in contrast to interest-bearing time deposits and other parts of the broader monetary aggregates. Monthly data on commitments have been collected only since 1975. Rates of growth since 1975 of $M_{1 \mathrm{~A}}$ and $M_{1 \mathrm{~A}}$ plus unused commitments - an expanded version of immediately spendable balances-are contrasted in figure 2 . They suggest that, at times of divergence, the more inclusive measure may be more revealing. ${ }^{6}$

The fresh memories of the 1966 credit crunch made it even more certain that the mid-1968 tax increase, over which so much political blood was spilled, would be drowned in a sea of credit expansion. Interest rates had rebounded to the brink of disintermediation. The tax increase was enacted in a climate in which passage was seen as a virtually certain signal for a strenuous Federal Reserve effort to depress interest rateswhether because of fear of "overkill" or of some tacit understanding with the other arms of government to trade lower interest rates for higher taxes. In a manner since repeated many times, the financial community saw the prospect of lower interest rates-through Federal Reserve action, recession, or both - as a strong incentive to expand the supply of credit. Coupled with the natural tendency of the public, in conditions of full employment, to maintain or expand its consumption in the face of the tax increase, the outcome was an explosion of bank credit. The crowning irony was that fiscal 1969, the only year between 1960 and the present to show a federal budget surplus, also recorded clearly the worst inflation since the Korean War. In fiscal 1970 the inflation accelerated further.

6. By 1977 , when such data began to be collected systematically, roughly onehalf of new long-term and short-term commercial and industrial bank loans, as well as construction and land development loans, was made under previous commitments. 
Figure 2. Rates of Growth in $\mathbf{M}_{1 \mathrm{~A}}$ and $\mathbf{M}_{1 \mathrm{~A}}$ plus Unused Loan Commitments, 1975:2-1980:2a

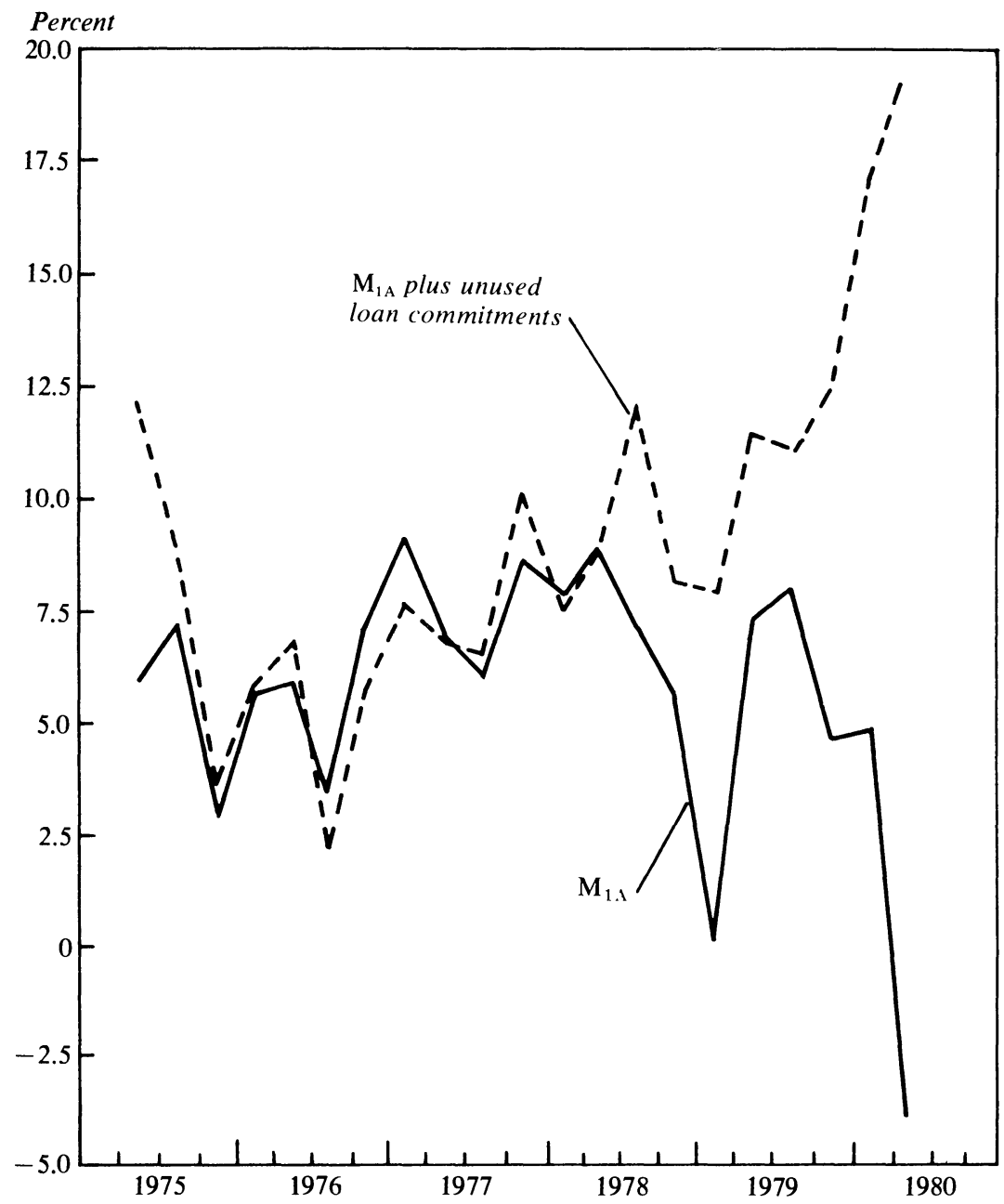

Source: Board of Governors of the Federal Reserve System. The data for unused loan commitments are based on "Loan Commitments at Selected Large Commercial Banks," Federal Reserve Board Statistical Release, G.21 (September 1980), and earlier similar releases.

a. Quarterly changes at seasonally adjusted annual rates.

That episode may be regarded as the paradigm for a sequence repeated (as will be described below) several times since. Government and lenders regard nominal interest rates as "high," foretelling recession and lower rates. Thus the supply of credit enlarges as lenders are encouraged to become aggressive. Meanwhile, credit demand remains relatively 
strong. Nominal GNP is at peak levels. Some sectors are still expanding. In other sectors that may be weakening, retardations in cash receipts are not immediately offset by expenditure cuts; these sectors may become larger and necessitous borrowers. In conjunction with a more accommodative monetary policy, the combination of larger credit supply and demand implies a sizable stimulus to spending. The short-run result is that, to general "surprise," the recession and lower interest rates fail to materialize. The long-run result is that the "high" interest rates, by bringing about a premature easing of credit conditions and Federal Reserve policy, serve as instigator rather than deterrent to the inflationary process. ${ }^{7}$

By 1969 deposit-rate ceilings were no longer a serious constraint on banks or their customers, but thrift institutions and the mortgage and housing sectors dependent on those thrift institutions were not so fortunate. As far as commercial banks were concerned Eurodollar borrowings, only an emergency resort in 1966, substituted admirably for the CD market whenever it became immobilized by rate ceilings. The creation of bank holding companies to issue unregulated commercial paper served the same purpose. The Federal Reserve, though well aware of the Eurodollar and other breaches, had learned enough to be careful not to close them. Some of the concerned parties recognized that, if the Federal Reserve chose to limit the quantity of bank reserves, this constraint could not in the aggregate be circumvented by $\mathrm{CD}$, Eurodollar, or any other open-market borrowing - but the constraint was viewed as falling on someone else. Few major bankers and their customers viewed themselves as individually constrained, and so the Federal Reserve was continually faced with stronger business plans and higher interest rates than it had foreseen.

At this juncture, high inflation and interest rates were still regarded as temporary, wartime phenomena. For both lenders and borrowers, the perceived real component of long-term rates had increased sharply. With Vietnam peace rumors (implying disinflation and lower interest rates) sweeping the markets as regularly as waves pounding a beach, lenders remained aggressive even as interest rates soared, while borrowers, as is usual when business is strong, did not seem to care.

The turning point in the financial sector had a different source. Banks

7. There is also the implication that once expansionary forces have taken hold, the Federal Reserve can contain them only by remaining "tight" beyond the time that will subsequently be recorded as the cyclical peak. There is no kill except overkill. 
raised the prime loan rate frequently in response to their rising Eurodollar costs, foreshadowing the formula-adjustment systems for the prime rate instituted a few years later. But in June 1969 they overreached themselves in lifting the rate a full point, from $71 / 2$ to $81 / 2$ percent, in one gulp. The resultant congressional outcry carried the message that banks should no longer count on being able to pass on higher money costs to their customers. The game had been shut down.

Although short-term rates continued to escalate rapidly to year-end, the prime rate moved up no further. Because lending had suddenly become unprofitable, banks tried to reduce loans rather than to expand them. Growth in bank credit virtually halted. Industrial production was declining by Labor Day, and recession was under way by Thanksgiving. Quite obviously, ceilings on loan rates can cause credit crunches perhaps less abruptly but just as effectively as ceilings on deposit rates.

\section{The Early 1970s-Penn Central}

At first it appeared as though the economic downturn in 1969-70 might be a replay of 1966-67. But the pace of institutional change in finance was accelerating. In early 1970 the Federal Reserve switched decisively to a monetary aggregates policy. The ceilings on $\mathrm{CD}$ rates were liberalized in circumstances that made clear they would no longer be used as a policy tool. As interest rates plunged, lenders' profit margins were restored. Credit expansion resumed and signs of economic revival multiplied. But the monetary aggregates expanded more rapidly, too, and the Federal Reserve tightened its money-market posture. Thus the market had reason to move rates up again and to foresee further increases. Uneasy feelings were deepened by the ugliness of the domestic mood related to the Vietnam War. A Treasury financing (then still conducted with the price set in advance rather than by auction) nearly failed when the Cambodian invasion began while the books were open.

All these considerations were suddenly rendered moot by the failure of the Penn Central Transportation Company and particularly by the defaulting of its commercial paper. This was one contingency for which the business and financial community of 1970 had not thought to prepare. Heroic emergency measures were taken by the Federal Reserve, and were fortunately successful, to assure the refinancing by banks of billions 
of commercial paper borrowings by companies large (notably Chrysler) and small. One of the key measures was the suspension (once and for all, as it developed) of any Regulation Q rate ceilings on CDs of less than three months. But even though financial catastrophe was averted, shock at the narrowness of the escape was profound. It prompted an instant toughening of credit standards by lenders and a reduction of perceived borrowing capacity by business firms. The short-range impact lasted until it was swept away by the commodity boom of 1973-74; some longerrange reverberations still echo today.

Although the Penn Central bankruptcy followed a long span of financial stress in the economy, it would be difficult to argue that the time, place, and outcome of such a failure was or ever will be predictable. Prolonged periods of intense inflation, speculation, monetary restraint, and rising interest rates set the scene, but whether and when a weak link in the credit chain may snap in a vital place remains very much a matter of accident. As a consequence, machinery for limiting the damage may not exist or, as in the case of Penn Central, may depend for its timely activation on energetic public officials willing and free to take controversial steps on the basis of fragmentary information. Credit crunch by private accident is much more dangerous than credit crunch by regulatory design or even error but, as this chronology of events is designed to emphasize, as crunch by design is ruled out, crunch by accident becomes more probable.

Recovery from the 1969-70 recession was sluggish, precisely because the attitudes of business borrowers and of lenders had changed. Grudgingly, the earlier widespread view that inflation and other problems would vanish with the de-escalation of the Vietnam War was abandoned. Instead the fear took root, rightly or wrongly, that any resumption of rapid economic expansion would also mean a prompt return of inflation and related financial stresses, including bankruptcies like Penn Central. While household sector credit expansion revived much as before, in the business sector both borrowers and lenders had grown more cautious. As a result, economic recovery (apart from the statistical rebound due to the end of the long strike against the General Motors Corporation) was sluggish while inflation hardly abated. Recognition of this "inflationary expectations" problem by the authorities eventually became one of the rationalizations for the price-wage freeze announced, in conjunction with devaluation, on August 15, 1971, to the general applause of the business and 
financial community. Other occasions will arise, I believe, when the dismantling of institutional credit constraints ultimately turns out to be part of an undesirable long-run trade-off for price and wage regulation.

The new incomes-control machinery included the Committee on Interest and Dividends - an interdepartmental committee, which for a time enforced an implicit prime-rate ceiling of 6 percent. This did not matter much in 1971 and 1972 while, with inflation and the balance of payments "taken care of" by controls and floating foreign exchange rates, the Federal Reserve was able to pursue policies that held down money-market rates. Of course such policies also promoted more rapid monetary and credit expansion. Coupled with expansive fiscal measures and the stimulative effects of devaluation, they led eventually to renewed pressures on physical capacity - and on interest rates-in early 1973. A confrontation between the ability of the banks to pass on rising money rates that the Federal Reserve was no longer able to contain and the implicit 6 percent prime-rate ceiling became unavoidable. The situation paralleled that of mid-1969, including congressional threats to impose a legislative rate ceiling if the Committee on Interest and Dividends (chaired by Federal Reserve Chairman Arthur F. Burns) gave way. But the outcome was different.

\section{Floating Loan Rates, a Digression}

Commercial bankers had realized for some time that their 1969 problems were apt to recur. In preparation, First National City Bank of New York in October 1971 initiated a policy of resetting its prime rate every week based essentially on a three-week moving average of money-market rates (using a specific formula several times revised since and not necessarily followed mechanically). Other banks followed de facto if not de jure. In this way, bankers hoped to draw the political sting from rate increases and, in effect, to shift the responsibility to the monetary authorities.

The action also fitted well into a larger context. Most nations no longer pursued anti-inflationary policies with great conviction. Exchange rates were no longer fixed. Abroad, business loan contracts with floating interest rates had become commonplace and bankers judged correctly that they would soon be equally appropriate in the United States, that is, a 
shift to floating rate loans would enlarge the total quantity of credit. And so it did.

Interest rates on floating-rate loans are tied, generally for the entire term of the loan or loan agreement, to the prime rate (or some other index). Thus every time the floating prime changes, rates are adjusted accordingly for a large body of outstanding credit. Data for the incidence of floating rate loans (as well as for loans made under previous commitments) have been collected only since May 1977. By then about half of all business loans made carried floating rates.

Under fixed loan rates, borrowers and lenders had always to consider not only whether the rate was right, but whether the time was right. Lending institutions typically "transform" shorter-period deposits into longerterm loans. However, if rates fell, borrowers were often able to refinance loans incurred earlier at the new lower rates. Lenders sacrificed relatively little by permitting a downward float. When money costs rose under a fixed-rate regime, on the other hand, lenders in general were unable to call in low-rate loans made earlier. Thus an upward float removed a major, conceivably even mortal, element of risk. Under floating rates, if default risk is ignored, the lenders' object simply is to maximize their assets, because a positive margin on every asset is regarded as virtually guaranteed.

For some business borrowers the timing of loans also involved a considerable element of risk. A firm saddled with high-rate loans because of poor timing was at a cost-price disadvantage to its competitors. Previously, high interest rates at times may have exerted a deterrent effect on borrowers not because the interest rate was too high, but because the rate was expected soon to decline. Under floating rates this risk, in most cases quantitatively small and extraneous to the main concerns of the enterprise anyhow, virtually vanished.

These considerations were coupled with a fallacious form of reasoning that appeared to make interest rate changes irrelevant altogether. Such changes were held to be mechanically linked to changes in the rate of inflation. But the rate of inflation, it was argued, would impinge equally on the borrowing companies' net revenues. Thus, unless the real rate was initially set too high, the float was of no consequence to the borrower. However, the initial real rate was bound to be low (even apart from tax considerations) because the major banks enjoyed the primest of credit ratings and lowest borrowing costs; they could always choose to borrow at a low point in the yield curve; and, most important, they viewed float- 
ing assets as riskless profit sources and thus were trying to expand them infinitely: a loan not made instantly by one bank would be made by another. The competition among banks ensured that borrowers would have to pay only small markups on the low money rates paid by the banks themselves.

These are still the largely prevailing conditions in the world's major business and governmental loan markets. They have been tempered by the lesson that as inflation increases, the dispersion of particular prices may also increase, so that for many companies an upward floating interest rate is not automatically compensated by the inflation of its own profits. Nevertheless, under the floating rate regime, extraordinarily violent fluctuations in the interest rate-surpassing those recently experiencedwould probably be required to restore any feeble cutting edge that the cost of credit once may have possessed.

Insofar as lenders perceive or actually experience reduced risk due to floating rates, their need for capital is reduced. For financial institutions especially, the risk of interest rate fluctuations has traditionally been among the chief considerations of capital need. The shifting of these risks back to the borrowers would imply a possible capital redundancy among existing institutions. Microeconomic considerations would suggest a reduction of bank capital ratios and an expansion of risks (wittingly or unwittingly) in other directions. Both appear to have occurred. The implication is that the frequency of defaults will increase and that consequently ex ante evaluation of default risk (including risk due to the borrower's vulnerability to extreme interest rate fluctuations) will regain a more important role in the way the market allocates credit.

The obverse also holds: nonfinancial business will need a stronger capitalization for a given amount of investment. Furthermore, an incentive is created for new techniques of hedging interest rate risks that bypass the traditional financial channels. I return to this subject below in the discussion of the financial futures markets.

\section{The Mid-1970s-Franklin National}

From February to April 1973, the Committee on Interest and Dividends, with its feet held to the fire by various congressional proposals to legislate formal controls, did in fact reluctantly hold down the prime rate 
to the 6 percent mark while money-market rates rose further beyond in response to Federal Reserve efforts to curb the rapid monetary expansion. But then a face-saving formula was found that effectively removed the restraint on the prime rate. Shortly thereafter, the remaining CD rate ceilings (on CDs of more than three months) were suspended. The controls on bank credit supply were demolished at a time when a large excess demand lay waiting. An explosion in credit growth and aggregate demand had been rendered a predictable certainty.

Released from its tether, the interest rate level spurted upward: from April to August 1973, the prime rate soared from 6 percent to 93/4 percent. Bank credit expansion persisted at an extraordinary pace. Then came a metamorphosis of market sentiment like that of mid-1968. The unprecedented interest rate levels began to be seen as forerunners of recession. The economic expansion slowed, partly because of disintermediation-induced weakness in housing, but probably mainly because of capacity bottlenecks in various industries. Possibly in response to the rise in short-term rates, excessive growth in the money stock gave way to a brief absolute decline, which the market knew would impel the Federal Reserve to bring short-term rates down. The market was right about the Federal Reserve but not about the recession. An extraordinary pace of credit expansion persisted. The outcome was that, although output dipped as a result of the Arab oil embargo of October 1973, no genuinely cyclical recession took place until nearly a year later.

Admittedly the business cycle chronology of the National Bureau of Economic Research shows a contraction beginning in November 1973. Most observers probably now agree that this dip reflected primarily the oil crisis and its short-run impact on automobile production and travel. Once the Arab oil embargo was lifted in March 1974, industrial production quickly rebounded. In early 1974 the view was popular that the recession was over and that the economy was entering the promised land of permanent shortages and double-digit inflation. The genuine hallmarks of a broad cyclical recession did not appear until fall 1974. That the economy managed to resist for so long in the face of the sharply higher interest rates, the severe declines in home building and automobile production, the food crop deficiencies, and the oil shock - not to mention the Watergate political trauma-is a strong testimonial to the motive power of the credit system when the participants see incentives to expand.

The credit market developments in the second half of 1973 initiated 
another pattern that has subsequently become familiar. A spurt in the money stock above the Federal Reserve's target range triggered a sharp rise in short-term rates, which was understood and expected by everyone. With the prime rate lagging a few weeks behind the upturn in market rates, banks experienced an unanticipated rise in loan volume, as corporations switched their indebtedness out of commercial paper into bank loans and tilted their marginal decisions between borrowing and shortterm asset liquidation toward borrowing. The banks thus were forced into the $\mathrm{CD}$ markets as necessitous issuers, intensifying the upward pressure on short-term rates. In due and rapid course, however, the spurt in rates induced the further economization of demand deposits. Monetary growth was brought within target and the whole wheel began turning rapidly in reverse, with commercial paper rates and bank loan demand unexpectedly falling, and so on. It is questionable whether any of these developments had any significant impact on real output-other than perhaps through the inordinate noise (vocal and statistical) that they introduced into the policy and forecasting process.

In spring 1974, money stock, inflation, and interest rates were again racing one another upward. The chase was halted not by any policy actions, but by some dangerous accidents. First and probably most important was the effective failure, in May, of the country's twentieth largest bank, the Franklin National. As in the case of Penn Central, the direct impact was quickly erased by a Federal Reserve bailout. But where the Penn Central default for a time paralyzed the commercial paper market, the Franklin near-default rendered it difficult if not impossible for all but ten or fewer of the nation's largest banks to count on being able to roll over their maturing CDs. Thus for most banks the making of new loan commitments based on prospective $\mathrm{CD}$ issuance was out of the question.

The banks' problems were compounded by the fact that many had set up real estate affiliates (REITs) that had used short-term borrowings to finance large real estate and mortgage acquisitions during the lending binge triggered by expectations of lower interest rates that dominated the latter part of 1973. The renewed surge in short-term rates brought many of the REITs to or beyond the edge of bankruptcy, further clouding the reputation of the sponsoring banks. Meanwhile, the REITs' efforts to liquidate real estate helped to disable a key link in the inflationary spiral.

The failure of the small Herstatt bank in Cologne, Germany, involving defaults in foreign exchange settlements, extended distrust of banks to 
an international scale. In this case, too, prompt action by the central bank prevented the most serious damage but could not equally promptly allay the new sense of risk the market participants now brought to transactions that formerly had been regarded as routine.

But central banks and the public, as before, paid a fearful price for these lender-of-last-resort operations, which encouraged banks to become more reckless lenders than ever. Once the dust had settled, both central banks and market participants came to regard such rescues as reliably institutionalized responsibilities. It is now everywhere taken for granted that no monetary authority will allow any key financial actor to fail. In 1980 the markets paid virtually no attention to the silver (Hunt brothers), First Pennsylvania, and Chrysler debacles, each of which would have had traumatic consequences not many years before. When the Hunt news, the most unexpected and immediately dangerous of the three, broke on March 27 , the Dow Jones average of industrial stock prices plunged 25 points by 3:30 p.m., but recovered all but 2 points of this drop in the final half hour of trading and soared 18 points the following day.

A further critical element in the credit crunch of summer 1974 was that, at midyear, the banks temporarily gave up their policy of keeping the prime rate floating above money-market rates. Perhaps because they despaired of being able to stay ahead of federal funds rising at a pace approaching 1 percent a month-I have not been able to elicit any other explanation, on or off the record-the prime generally stopped at 12 percent, while federal funds soared on to $131 / 2$ percent in early July. Thus the summer 1969 constraint of negative marginal revenue on new loans was reinstituted, producing the same sure and swift curtailment of credit growth and aggregate demand.

\section{5-78: Waiting for the Next Recession}

Market participants were left deeply concerned, as they were after the Penn Central experience, that a vigorous business revival might lead to an early recurrence of the painful scenario of inflation, bankruptcy, and asset-price collapse. In September 1975, when short-term rates were at not much more than half their levels of summer 1974, bond yields responded to the rapid business recovery by vaulting back almost to the 1974 high. After this the economic expansion slowed to a more sober 
pace. Indeed, the entire period from the onset of recovery in spring 1975 to about the middle of 1976 was one in which fears of a recurrence of that painful scenario kept lenders relatively reluctant participants. By hindsight, the trend of long-term interest rates was clearly downward, but the period was punctuated by and is probably best remembered by bond market participants for several soul-searing upward interruptions, as each modest upward wiggle in rates was suspiciously regarded as a possible herald of doomsday.

This climate changed abruptly about mid-1976, in one of those mysterious shifts of financial market style that resembles the epidemic eruption of a successful pyramid club. Forecasts of recession came into renewed vogue and remained popular throughout the three and a half years of waiting for the actuality. The style of lenders correspondingly returned to aggressiveness. Meanwhile, as virtually throughout the period under review, the borrowers "ye have . . always with you," that is, there is normally a sizable fringe of unsatisfied credit demand that can be actuated whenever lenders decide to ease the nonrate terms of credit. In the event, bank credit soon exploded. Monetary growth followed. By early 1977 the pace of economic expansion reaccelerated greatly, led by the most creditsensitive sectors. The trend of interest rates also turned upward at the beginning of 1977, but then-inverting the previous relation-it was the frequent but abortive bull market movements to lower rates that became the memorable events.

By spring 1978 enough steam had accumulated in short-term interest rates to threaten another serious bout of thrift institution disintermediation. This the authorities evidently were not prepared to face. For the first time, they authorized the issuance of savings instruments carrying a money-market rate: the six-month money-market certificate (MMC). The explosive response to this innovation paralleled what had happened five years earlier when commercial banks were released from prime and CD rate constraints. Now it was the thrift institutions (including smaller commercial banks) and their customers who were freed to make effective their excess demands for credit and assets. Like banks with CDs and Eurodollars, thrift institutions could be certain of retaining most of their deposits in the face of a rise in money-market rates. The cost might become burdensome, but this did not trouble the institutions until it actually happened. Moreover, the only way to offset the rise in costs was to acquire more new and high-rate mortgages, not fewer. The subsequent real-estate 
centered inflation and interest rate explosion had been rendered a predictable certainty. ${ }^{8}$

At that time, as always, the authorities were wrong to presuppose a significant interest rate elasticity in aggregate credit demand and were unwilling to admit their mistake. The escalation of general interest rates, as the surge in the interest cost of savings accounts fed through to borrowers, was read by government and market alike as a portent of imminent recession - a reason for the market to acquire more fixed-rate assets and for the government to relax efforts at restraint. ${ }^{9}$

Businesses and households, however, were not fooled. To them, rising incomes, ready credit access, and the rapid price rise in credit-financed assets spoke more loudly. Another whirl launched around the vicious circle in which each move to higher interest rates prompts the authorities to relax their concern about credit expansion and thus to accommodate more inflation (and eventually still higher interest rates).

\section{The Inherent Weakness of Housing, Another Digression}

As events have subsequently demonstrated, the reprieve afforded to home building by the MMC was rather brief and was purchased at a high price in national inflation. The error stemmed not only from the misplaced faith in demand elasticities, but also from a misperception that the cyclical vulnerability of home building results from a weakness in the financial institutions that have traditionally provided mortgage funds, rather than the other way around. This misperception accounts for earlier efforts to use federal agency funds in support of housing finance, when at the critical times the financing of the agencies themselves, and their own

8. In just two years, about $\$ 380$ billion of these MMCs came to be outstanding. There was also a mere $\$ 60$ billion increase in the fledgling money-market funds, another aspect of the revolution in asset preferences wrought by deregulation of the interest rate. Most money-market funds (and even a few MMC accounts) permit owners to write checks on these balances. It is hard to imagine how any relevant econometric results using data predating these new instruments can remain applicable.

9. The syndrome reached its epitome when the credit restriction package-including a 1 percent rise in the Federal Reserve discount rate-announced the morning of November 1, 1978, in response to the desperate weakness in the dollar was greeted with a continuing rise in bond prices by the close of the day. Given this reaction, was the impact of this package restrictive or expansionary? 
efforts to maintain liquidity, have always intensified rather than mitigated the interest rate and disintermediation problems. Similarly, guaranteed Government National Mortgage Association (GNMA) pass-through securities and other mortgage-backed marketable securities have been remarkably successful in attracting pension funds and other institutional lenders into the mortgage market-so that now at times of stress, mortgages are offered not only by would-be-borrowers but also by holders of existing mortgages and related securities.

In a "crowded" credit market, as is well understood, long-lived assets and homes in particular suffer a competitive disadvantage compared to shorter-lived machines. When real interest rates rise, the cost of acquiring a new home increases faster than the cost of new machines (and the purchase price of the existing housing stock declines faster). To the extent that demand for housing is relatively interest-elastic, as is generally believed, resources will be transferred out of the home-building sector. ${ }^{10}$ It is at least questionable, however, whether the short-run interest rate elasticity of housing demand, especially as modified by housing inflation and by tax considerations, is large enough to account for the huge cyclical swings in home building.

However, housing has other important handicaps. A new owner-occupied home, unlike a new machine, does not yield incremental output that the owner can expect to turn into a cash flow to meet obligations. Whenever nonprice credit rationing emerges, therefore, machines gain in creditworthiness at the expense of owner-occupied homes. This is another, and conceivably quantitatively more important reason why home building is doomed to be the first industry crowded out whenever credit tightens.

An index of housing's competitive frailty has been the widespread dependence of mortgage financing on near-money, short-term deposits paying below-market rates of interest. It is most unlikely that the public would have been willing to substitute longer-term higher-risk, or illiquid assets for its savings accounts at anywhere near the prevailing interest rates. Now that interest rates and public access to various near-money assets have been largely deregulated, it will become possible to assess how important this subsidy to home building may have been. Will the public appreciate the trade-off whereby it will earn higher but widely diffused

10. Such elasticity does not imply a corresponding elasticity for other sectors or for aggregate credit demand. As an extreme example, consider the case of a gigantic federal budget deficit. 
and for most households rather small interest incomes at the expense of having to pay more (and possibly incurring stiffer nonprice terms) when taking on a mortgage?

The underlying reality is that single-family homes make no private or public technological sense-enormous efficiencies in private and social capital could be realized if people would live in small apartments near their work places (actually in factory dormitories, as once was common). However, in expression of the deep human craving for personal space, it is precisely this "inefficient" form of tenure, homeownership, that is heavily subsidized throughout the industrial world. The dependence on subsidy is evidence of the inefficiency. In view of housing's "constitutional weakness," it is to be expected that freeing the financial markets-which in the United States is tantamount to shrinking the housing subsidy by withdrawing preferences hitherto accorded mortgage-lending institutionswill reduce home building. Freeing the thrift and mortgage markets from governmental subsidy and guarantee is like freeing family pets by abandoning them in the jungle.

Fighting this reality has meant the prolongation of periods of accelerating inflation, thereby promoting the embedding of the inflation in longterm wage and other contracts and through various indexing devices. One great advantage of the disintermediation credit crunches was that everyone knew in advance that the intervals of intense inflation and peak interest rates before the crunch, as well as the crunch itself, would be mercifully brief.

\section{The Crunches of 1979 and 1980}

As 1978 turned into 1979, most of the forecasting community-including economists, Wall Street, businessmen, politicians, the mediacontinued to gird, anxiously or eagerly depending on the point of view, for the allegedly imminent and inevitable recession. The money stock actually fell, but credit continued to expand rapidly. Between then and now, two economic downturns were still impending, but both underlined the overwhelming importance of availability and the subordinate role of price in business-cycle timing.

The first setback, in spring 1979, resulted from the sudden reemergence of the gasoline shortage and hoarding syndrome. As in 1974, the 
economic weakness evanesced just as soon as gasoline became freely available again, even though the renewed availability came at an enormously higher price. Of course the permanently higher oil prices depress the economy (as do higher real interest rates), but the impact appears to be secular, not cyclical.

There are instructive resemblances between the role of oil and of money/credit. Both are essential and universal ingredients in the functioning of the modern interdependent, specialized economy. The propositions that "my spending is your income" and "my driving is your income" are virtually interchangeable. For money, the law forbids any substitute, although the law can be and to some extent is circumvented. For oil, and particularly gasoline, there are virtually no short-run substitutes. For both money and oil, output is monopolistically controlled by a central authority, be it the Federal Reserve or OPEC, that does not operate on any simple short-run profit motive. Not surprisingly, therefore, exogenous shifts in the supply of oil and money have similar consequences and much can be learned from one about the other. ${ }^{11}$ In the context of this paper, what is noteworthy is that on two separate occasions (late 1973 and early 1979) the U.S. economy in the advanced, supposedly vulnerable stages of cyclical expansion was garroted by a severe unanticipated constriction of oil supply, immediately responded with a sizable decline in aggregate output, but instantly revived once the shortage ended despite enormous and largely permanent price increases in the universal quantity, oil.

In these "experiments" the economy replicated its behavior to monetary restraint and crunches. Higher interest rates have had little cyclical impact. Only crunches have brought cyclical downturns, and these have been brief as long as no deep institutional damage was done. This is not surprising; in contrast to the oil situation, the political authority that occasionally permits a credit shortage is under our own control and can safely be expected to undo the shortage and bring down the price rather promptly.

In the 1979 episode, the fact that the macroeconomic consequences of

11. For example, the consequences of beliefs that the real oil price will undergo a never-ending rise are analogous to those that would occur if real interest rates were expected to be rising forever. In both cases, for expansionary macroeconomic policies to be effective, they must inflate the prices of other items so rapidly that oil or money will seem unexpectedly cheap. 
Figure 3. Credit Commitments of Banks, January 1975 through July 1980 ${ }^{a}$

\section{Billions of dollars}

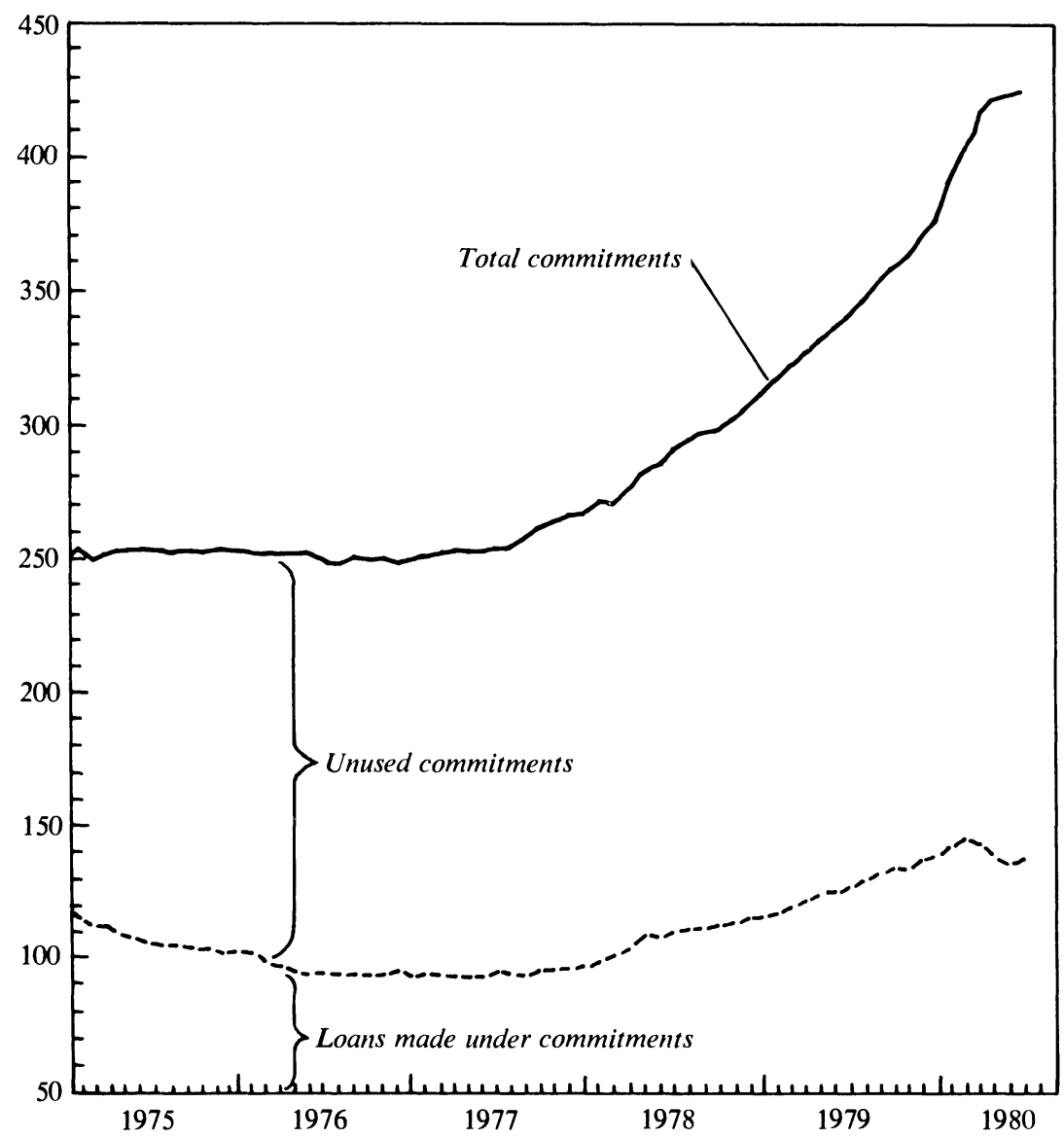

Source: Same as figure 2.

a. Seasonally adjusted monthly data at annual rates.

the gasoline shortage were widely misread as a "genuine" recession prompted reactions in the private market and by officials that promoted a veritable credit eruption. For total loan commitments at large banks (shown in figure 3 ), the growth rate accelerated to a seasonally adjusted annual rate on the order of 20 percent in each of the first three quarters of 1979 , and 24 percent in the fourth. The increase in these loan commitments relieved companies of any serious concern about a scarcity of spendable funds. The October 1979 spurt in interest rates and change in 
the Federal Reserve's mode of operation to reserve targets exerted no perceptible retarding influence. (An exception was the mortgage sector, but only because usury ceilings came into play in several important states until they were suspended and, more recently, in effect abrogated under federal law.) In the first quarter of 1980 , with possible anticipation of credit controls becoming more of a factor, the growth rate of commitments accelerated to 41 percent. Even after mid-1980 when interest rates had come down sharply from the convulsive peaks and were rising again, the chief concern of financial intermediaries appeared to remain how to lock in what were still regarded as transitory high rates. In my view, no conventional recession would have developed in 1980 until it was triggered by a sufficiently severe repeat of a Penn Central or Franklin National calamity - were it not for a new type of credit crunch that was introduced, abruptly and probably largely unintentionally, by the Federal Reserve credit control measures of March $14 .{ }^{12}$

The shock to the economy from these measures primarily reflected two novel features of credit control. First, marginal reserve requirements were imposed on nonbank consumer credit lenders, who had not experienced any official regulation since the Korean War almost thirty years before. ${ }^{13}$ The impact was much more than psychological, however. Because of the jump in short-term money rates to the 20 percent range, most of these lending institutions were already suffering negative marginal revenue on new loans, inasmuch as ceilings set by state usury laws generally prevented full pass-through of these costs. Until March 14, the prevailing view among major consumer finance companies had been that these high money costs were transitory, and that the way to gain market share was to lend aggressively when competitors might be falling by the wayside. Now these institutions were persuaded, much as were the commercial banks in mid-1974, that a lending curtailment was going to be enforced no matter what happened. Because lending entailed out-of-pocket losses anyway, their response was immediate.

Second, in the commercial bank sector, the setting of loan growth ceilings spread alarm among borrowers and lenders alike. Although the annual percentage increases permitted were designed to be reasonably com-

12. For a description of these measures, see Federal Reserve Bulletin, vol. 66 (April 1980), pp. 314-18.

13. The "truth-in-lending" regulation is more recent in origin, but is of a different character. 
fortable, no one could feel secure about this so early in the year, especially in view of the multibillion spurt in formal credit commitments written just previously. From the point of view of borrowers, their "credit crunch insurance"-effectively, their precautionary money balanceshad just been wiped out. If one's bank was beyond its ceilings, commitments might not be honored. From the point of view of the banks, it became urgent to cut other lending so as to manage if called upon to honor the legally binding commitments. Consumer loans were the "cheapest" loans to curtail because they were currently unprofitable and because they did not involve long-term customer relations. So the lending windows suddenly closed, much as had the gasoline stations a year earlier, and with parallel consequences. In case after case, business contacts reported, often in the identical language, that instantly after March 14 it was as though "the curtain came down." ${ }_{14}$

After mid-1976, when the personal saving rate first dropped below the 6 percent of disposable income that observers had somehow come to regard as a threshold, the forecast of an imminent consumption-led recession was voiced widely. These views failed to give proper weight to the supply side of the credit market. To be sure, the savings rate had risen and recessions had followed in earlier periods of high interest rates, as the high rates induced some shift of consumer purchases from tangible to financial assets. But the main story of those periods, I believe, was the accompanying nonprice curtailment of credit supply to households-particularly of mortgage credit but usually of security and consumer credit as well. ${ }^{15}$ In 1980 it was the "crunching" of consumer credit between state usury ceilings and the new Federal Reserve regulations that precipitated the recession.

Already the aftermath is assuming familiar outlines. A brief crunch prompted a sharp recession. The authorities soon recognized what was happening and undid the climate of restraint. The recession ended shortly thereafter. The crunch machinery was dismantled amidst implications that, having seen its startling potency, future reuse was being forsworn. The private sector is developing new instruments which, seen from the

14. The impending April 15 corporate and personal income tax deadline, with its accompanying strains on liquidity, magnified the impact of the credit restrictions.

15. There are also conceptual and statistical problems in the measurement of household saving that render it extremely hazardous to suppose that the current figures will retain their shape under future revision, or that even the revised data will be trustworthy. 
standpoint of the individual participants, will render them immune in the future.

\section{Financial Futures}

The most promising of such devices involves the financial futures markets. With financial institutions shifting interest rate risk back to the borrowers by means of floating rates, a market is opened for a new device whereby borrowers may insure themselves against adverse interest rate fluctuations. Futures are in fact an instrument designed to guarantee potential users of a product that they will be able to obtain that product at a date certain in the future at a price specified today. Futures markets have a major "technological" advantage over cash markets because they concentrate trading in a small number of narrowly defined contracts, creating a highly centralized market in place of a congeries of fragmented submarkets involving different commodity grades and delivery terms. Participants in an organized futures market no longer need to be expert in the arcane properties that might distinguish one variety of, say, wheat or Treasury bonds from other closely related types. Nor, as long as the market functions, do they need to hold or pay for the underlying commodity. Much greater leverage thus becomes possible.

From a commodities market standpoint, the extension of the futures concept to financial instruments represents a perfectly natural progression. Although the initial futures market, in GNMA mortgage passthroughs, was established as recently as 1975 , futures markets now exist and are proliferating in Treasury bills and bonds, as well as (much less successfully) in Treasury notes, commercial paper, and CDs. Recent trading volume in bill futures (about $\$ 14$ billion daily in face value) and bond futures ( $\$ 2$ billion daily) exceeds that in the cash market. ${ }^{16}$ It is now technically feasible for an enterprise to hedge changes in interest rates and to assure the liquidity of Treasury securities and related portfolios as far as two years into the future. Just as banks through floating rates have

16. In futures volume, each transaction (purchase and sale) is counted only once. In the cash market, figures refer to transactions by thirty-six currently reporting dealers; thus purchases and sales are in effect multiply counted. On the other hand, the initial margin is set at $\$ 2,000$ per $\$ 100,000$ in Treasury bond futures for some exchanges and at $\$ 1,500$ per $\$ 1,000,000$ for three-month Treasury bills, so that actual payments are much smaller than they are in the cash market. 
passed their interest risks to borrowers, now borrowers are learning to hedge these risks with the general public through the futures markets.

As sensible as all this is on a microeconomic scale, from the macroeconomic standpoint it promises trouble. Wheat, copper, and the like are presumed to be produced and sold in response to economic incentives. The participants in these commodities exchange markets are speculating or hedging primarily against market developments and random acts of God-droughts, storms, strikes, and so on. The production of new government securities and the means to pay for them, on the other hand, in general responds to political rather than pecuniary decisions. The siren song of the financial futures markets is that they offer to banks, builders, and all business the immunity to macroeconomic policies of restraint. In due course, the authorities can expect to be confronted by situations in which, familiarly, the alternatives are a financial crisis or the monetization of these new liabilities (promises to deliver funds at a specific price). However, as the historical discussion above has shown, in the end supposed immunity to financial risk always turns out to be illusory, and the risks and costs of shattering the illusion may be considerable.

The presumed insurance offered by the futures markets must be supplied and paid for. In this regard, futures markets have brought into the interest rate arena a new class of participants-commodity traders and wealthy individual speculators. The effect has been to render financial market prices more efficient (in the economics textbook sense) but probably in a way that reduces the efficiency (ordinary dictionary sense) of the economic system as a whole, which is populated by long-lived tangible assets and slow-moving human beings. ${ }^{17}$

The markets for securities with fixed interest rates have traditionally been dominated by risk-averse institutions. The broadening of these markets, through the futures linkage, attracts participants who are much more willing to accept risk. ${ }^{18}$ This is not to suggest that most futures volume in-

17. Kenneth Boulding's maxim cannot be repeated too often-that the "real name of the devil is suboptimization." We are exerting too much effort "finding out the best way to do something which should not be done at all. . . Obviously, the deep, crucial problem of social organization is how to prevent people from doing their best when the best in the particular, in the small, is not the best in the large." The performance of a tricycle will not be improved by adding a jet engine. Kenneth Boulding, Fun and Games with the Gross National Product, Collected Papers: Kenneth E. Boulding, vol. 3 (Colorado Associated University Press, 1973), p. 482.

18. Possibly the fact that the institutions are tax exempt or sheltered, while the new participants are not, may help to explain the difference in tastes. 


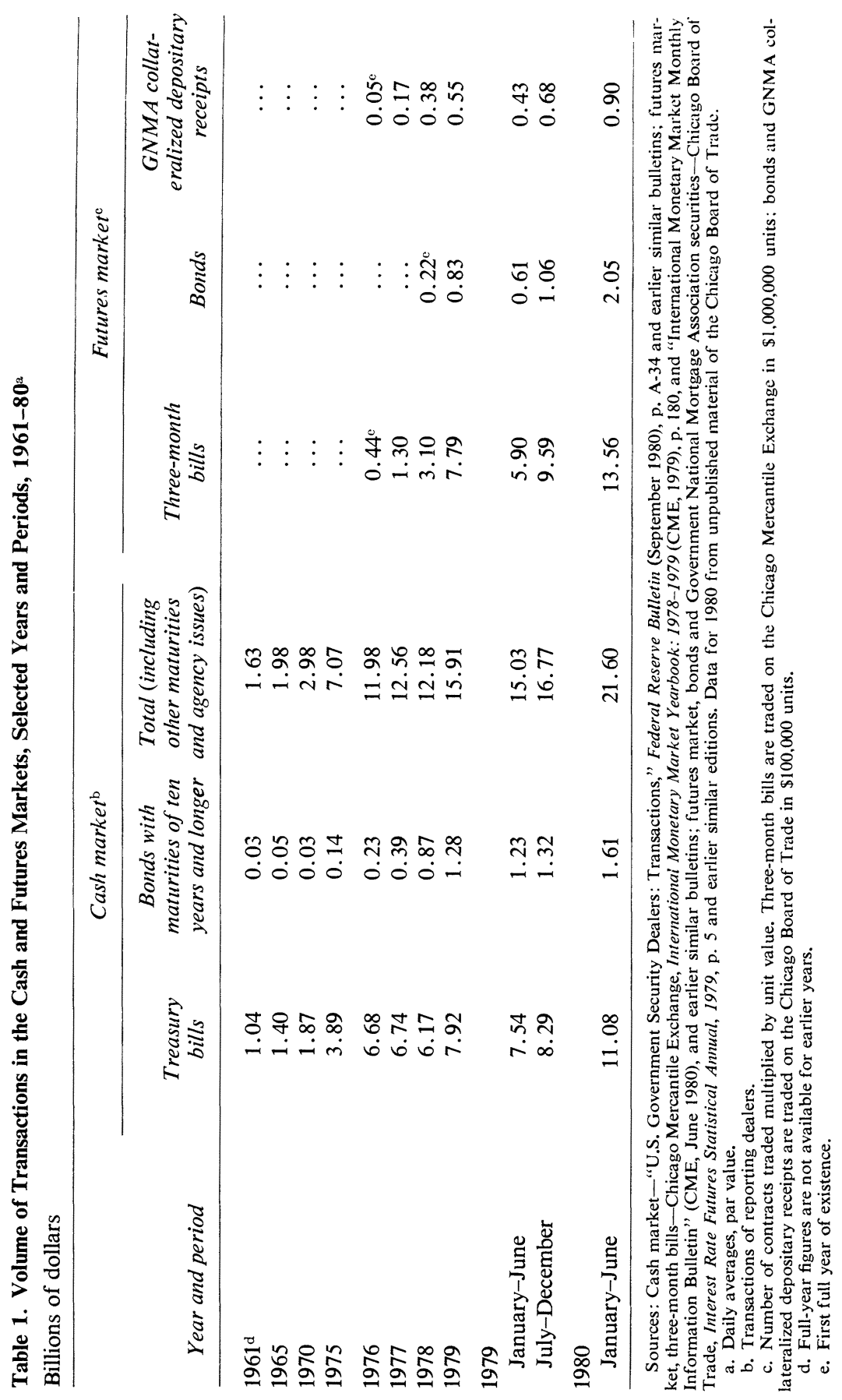


volves these new participants. To the contrary, dealers in cash markets and professional arbitrageurs are apparently the major transactors. But it is the commodities trader and the wealthy individual for whom the futures market has opened a door previously open essentially only to financial institutions. These newcomers draw on different types of information and form their market opinions in a different milieu. There has been a change in the tastes of the market, reinforcing the ever more prevalent "performance" (short-range) orientation of the cash market. As a result, current and future behavior of interest rates and, in turn, the economy, may differ from the past. Interest rates, it may be noted, have generally turned coincidentally with or, especially before the creation of the Federal Reserve System, lagged behind turning points in general economic activity, while commodity prices have tended to lead. It will be interesting to observe what pattern is produced by the marriage of these relations in the commodity pits - and what may be the feedback on the real economy.

The customers get the action they want. In the past year or so, the volatility of interest rates and the volume of transactions have increased enormously. In the Treasury and federal agency securities cash market, daily volume of reporting dealers in the first half of 1980 reached $\$ 11$ billion in Treasury bills and $\$ 10^{1 / 2}$ billion in other securities, about threefold the 1975 volume (see table 1). In 1970 the total volume was $\$ 3$ billion. The daily futures volume in the first half of 1980 reached nearly $\$ 1$ billion in the GNMA futures market founded in 1975. It reached $\$ 13 \frac{1}{2}$ billion in three-month Treasury bill futures and $\$ 2$ billion in Treasury bonds; before 1976 and 1978, respectively, these markets did not even exist.

When the financial futures markets were launched, most (perhaps all) participants regarded it as virtually unthinkable based on previous experience that there would ever be "limit" price changes (a one-day move of 2 price points in bonds or 50 basis points in bills). Such changes, which in effect halt trading, can have catastrophic consequences for participants. In fact, they have already occurred so often that they barely attract notice.

In the first half of 1980 , the daily average net price change in the cash market of Treasury 81/4 percent bonds due in 2005 (a representative long-term bond) was over $1 / 5$ of a point-equivalent to about $1 / 8$ percent -more than twice as large as during any previous six-month span since these securities were issued (see table 2). If one had data for intraday ranges or fluctuations, they would show an even more gigantic heightening 
Table 2. Volatility of Treasury Securities Yields and Prices, 1973-80

Daily average change ${ }^{a}$

\begin{tabular}{ccc}
\hline Period & $\begin{array}{c}\text { Six-month bills } \\
\text { (Basis points) }\end{array}$ & $\begin{array}{c}81 / 4 \text { bonds due in 2005 } \\
\text { (Price points) }\end{array}$ \\
\hline 1973: First half & 3 & $\ldots$ \\
Second half & 3 & $\ldots$ \\
1974: First half & 2 & $\ldots$ \\
Second half & 4 & $\ldots$ \\
1975: First half & 8 & $\ldots .31$ \\
Second half & 6 & 0.30 \\
1976: First half & 5 & 0.26 \\
Second half & 4 & 0.25 \\
1977: First half & 4 & 0.16 \\
Second half & 3 & 0.17 \\
1978: First half & 3 & 0.25 \\
Second half & 6 & 0.19 \\
1979: First half & 5 & 0.39 \\
Second half & 12 & 0.82 \\
1980: First half & 22 & 0.82 \\
July-August & 17 & \\
\hline
\end{tabular}

Source: Calculations by the author based on data available to The First Boston Corporation.

a. From the close of one day to the close of the next day. Does not reflect additional intraday fluctuations.

of volatility. These are rather large daily changes for a sober market to undergo in its opinion of average interest rates for the next twenty-five years. The daily net change in six-month bill yields showed a similar surge, to 22 basis points!

Instruments that resemble options have also begun to proliferate, and application is pending for official approval to trade Treasury bond and GNMA options. Because options, in contrast to futures, in essence embody an automatic stop-loss feature (the maximum loss is the cost of the option if not exercised), their speculative appeal may well exceed even that of futures.

The new climate reflects current realities, including new financial policies. As recently as the late 1960 s, the authorities stood ready to counter abnormally large bond price changes; now they have virtually completely abdicated any concern. The various ceilings on the interest rate that set bounds to actual and expected rate movements have been largely abolished. Short-run official intervention in the market depends importantly on frequently violent short-run fluctuations in money stock that are 
largely random in relation to the economic "fundamentals." Not surprisingly, therefore, movements of the interest rate have assumed more of the "random walk" aspects of other asset prices, and the gambling aspects of the markets for securities with fixed interest rates have become increasingly important. ${ }^{19}$ It defies belief that turnover of $\$ 38$ billion a day in just one segment of the fixed-income market is required to fix the rational allocation of capital. That so many major financial institutions now "trade" their bond portfolios, that is, try to outperform the market on a monthly or even weekly horizon, is particularly indicative of a gambling mentality, because from the point of view of the holders the total maximum return on the existing stock of bonds is fixed in advance by the nature of the bond contract. Interest and principal are given. The game is in the limit at best a zero-sum game, and because of transactions costs and defaults, a negative-sum game in actuality. The observed behavior merely confirms the strong human propensity, well documented over the millenia, to gamble - that is, to overpay for the privilege of playing a fair game. ${ }^{20}$ In unregulated asset markets structured to take advantage of this propensity, one should therefore expect a gamblers' premium to prevail. This, I believe, mainly explains the apparently low or at times negative real (after$\operatorname{tax}$ ) rates of interest so frequently observed (which turn positive mainly after times when the gamblers have had a particularly "bad trip"). It is also consistent with the view that in the financial behavior of individual economic units, bankruptcy fears far outweigh interest elasticities.

Thanks to improvements in electronic communications, the financial community has been molded into much more of a "crowd." Trading floors have always consisted of crowds in the literal sense. Now, however, the crowd has been extended to embrace all market participants who want to join, no matter how distant. The video screens that transmit instantaneous news and price information are standard equipment everywhere.

19. Keynes' famous observation is certainly no less warranted today than in his time: "The game of professional investment is intolerably boring and overexacting to anyone who is entirely exempt from the gambling instinct; whilst he who has it must pay to this propensity the appropriate toll." John Maynard Keynes, The General Theory of Employment Interest and Money (Harcourt Brace, 1936), p. 157. Much of this paper may be regarded as a pedestrian update on chapter 12 of The General Theory.

20. It may be that the propensity to overborrow, even at usurious interest rates, is simply another facet of the gambling mentality. In turn, this frailty of humanity in expecting the future to bring more luck than cold rationality would calculate may be essential to its biological survival. 
Traders must and do therefore respond literally instantly to all news to which they think other traders might respond. Whether the news is considered economically significant or even true is immaterial. Moreover, it is well known that crowds generate, transmit, and respond to messages (rumors included) very differently from individuals. Thus accident comes to play a large role. For example, a news item that appears while the market is open may elicit a much larger response in price, volume, or both than one that appears when the market is closed (when the crowd is disbanded), removing the carrot-and-stick pressures for instant response. Occasions are commonplace on which prices move in one direction in response to a news report but fail to move back when the report is unmasked as palpably false.

Volatile movements in the interest rate make it difficult to pursue either a purposive or stable monetary policy. Even advocates of a policy dedicated strictly to stable growth of the monetary base may recognize that wide rate fluctuations will intensify the political difficulties of adhering to course. Moreover, in a wealthy world there must be some threshold beyond which the macroeconomic wealth effects of even random fluctuations in asset prices become significant. Those who advocate less singleminded policies will find the market signals needed for policy calibration obscured by the increased noise from the larger fluctuations in interest rate. I cannot visualize a Federal Reserve of human beings standing at a point so physically and emotionally remote that they alone can stabilize a financial world that has no other discipline to keep it in check.

None of the foregoing is meant to suggest that participants make decisions other than those dictated by rational self-interest as they correctly perceive it, including recognition of the frailty of the monetary authorities. Consumer sovereignty reigns. ${ }^{21}$ In my view, however, this sovereignty has such serious negative externalities that financial markets should be recognized as one of the key sectors in which human collectivities see fit to impose restraints on individual impulse. It makes me rather uneasy to

21. In the case of fiduciaries-pensions, trust funds, and so forth-a conflict may exist between the manager of the funds who wishes to increase his or her income now, and the owner who may be financing retirement or building an estate to pass on to heirs. These days, however, the conflict may be more apparent than real. Owners seem to be apportioning and reapportioning funds among managers mainly on the principle of "what have you done for me lately?" If owners of funds look for managers who have shown above-average returns, they are opting for aboveaverage risk. 
observe that, in most years, the most talented business school graduates vie for employment in investment banking and related fields, correctly assessing the potential for early and large rewards; while it is left to lesser mortals to organize, for smaller rewards, the production and distribution of the goods and services that give underlying value to the claims and securities that the financial markets shuffle about.

\section{Expectations}

While having repeatedly asserted that expectations of financial market participants play a critical role in business fluctuations, I have thus far skirted any direct confrontation with the subject. What expectations are, and how they are revealed, is no simple matter to define or measure. According to the experience of public opinion polling, it certainly cannot be done with a naive questionnaire. How can one rationalize, for example, that at this writing the yield curve of Treasury securities slopes upward to the seven-year maturity and downward to the longer maturities-while the curve for high-grade corporate securities slopes upward throughout? Is there a simple explanation for why the yield on short-term tax-exempt securities has never exceeded that on long-terms, even during the extended periods during which the taxable yield curve was sharply inverse? Why is it that near every business cycle top, experienced observers know that a recession is on the way and are poised to "scalp" a bond price recovery even before it starts, yet as referred to above, long-term rates on average lag behind cyclical peaks in business. Moreover, this lag often has prevailed despite the signal given by an earlier crest in short-run rates. That is surely a curious performance for a collection of assets whose prices represent little more than congealed expectations.

In theoretical models of asset prices, complications ensue when the expectations held by market participants are not independent or identical. Yet as I try to illustrate below, the market may be viewed as a collection of overlapping crowds, with considerable diversity as well as interdependence of expectations both within and between the crowds. Indeed, it might be contended, the effectiveness of a credit crunch or comparable overriding polar force is its power to force market expectations all to point in the same direction.

It is commonly accepted that portfolios should be diversified to reduce 
risk. Such prudence also dictates that one's expectations be diversified (take into account many different future states of the world) - but this makes defining expectations or measuring them statistically a monumental task. Moreover, an economic unit may respond differently (to a questionnaire or in the market) as an individual than as a member of a crowd, and different crowds will respond differently depending on their horizons, endowments, noneconomic values, and so forth. The same economic news of undisputed contents is likely to evoke different judgments-and even when the judgments are the same, different market actions. Accidents that precipitate irreversible change, that is, events as opposed to statistical tides, often assume disproportionate importance when they provoke crowd response. My judgment is that accidents in the shortrun sequence of news and market responses frequently do affect the ultimate pricing outcome.

An obvious perceptual gap is that between public officials and the private sector. Many instances could be recited in which small acts of omission or commission by officials, of which they were barely or not at all aware, deeply influenced private decisions about whether to swim with or against the flow of public policy. Similarly, in the constrained circumstances of dialog between government officials and private parties, the latter may often unwittingly give cues that officials are prone to misread. In terms of financial markets, the gulf between the so-called Washington, D.C., and New York views has become almost legendary. Washington naturally tends to think more in terms of real magnitudes that usually adjust sluggishly, that is, in terms of flows and small incremental change. New York deals in financial instruments for which the possibility of rapid stock adjustment is ever prominent and can force more rapid adjustment of real flows than real-sector participants normally predict. But these are familiar and superficial (although not unimportant) discrepancies in sector expectations. There are deeper and more serious ones, both between and within sectors.

For example, one may surmise that it has been many years since any sizable proportion of households has believed that general inflation (as distinguished from surges reflecting particular developments such as oil price hikes or crop failures) was likely to diminish greatly for any sustained length of time. The purchasing behavior of households has surely been consistent with such expectations. Similarly, I can attest from continual interchange with key industrial executives that, except for high- 
technology new products, in recent years virtually none has anticipated any retardation in the rate of increase of unit labor and materials costs, or their own-product prices. Perhaps a few such expectations may have been held in 1975-76 and at intervals during the preceding decade, but not often. Yet during these fifteen years or so, the conviction that inflation would subside (or nearly vanish!) was often held sincerely and strongly not only by government officials, but by influential segments of the financial community. The extraordinary rate of placement of fixed-rate, longterm securities among all kinds of financial intermediaries testifies to these beliefs. Yet the information on which financial professionals acted was the same available to all, and their intelligence and economic understanding, I would venture to guess at the risk of losing many friends, is at least as high as that of captains of industry or the general public.

This chronic divergence in sectoral expectations is asserted as a fact. The explanation offered is conjectural. Financial managers are responsible for large agglomerations of paper claims and must invest large incremental flows. They would have to undergo drastic restructuring of education and habits to change their ways. Any decision on their part to make a lasting switch to short-term or floating-rate ("no decision") securities would tend to call into question the need for their expertise. It is psychologically debilitating to be heavily involved with a product one believes to be depreciating. Like manufacturers of large automobiles, financial managers find it hard to function without genuine enthusiasm. The fact that for big institutions, notably pension funds and life insurance companies, liabilities in general are not yet contractually indexed has prolonged the life span of this form of "money illusion." Paradoxically the fact that it does persist, as already pointed out, has played an important role in prolonging business expansions.

A reverse effect, as already suggested, is at work in the business sector. No company views itself as able to fight more than a delaying action against the encroachment of labor's demands. But unless the company assumes that the higher labor costs can be passed on (its own as well as those of its suppliers), it has no rationale for survival. Also, business firms by penalty of dealing with technological processes, bricks and mortar, and people_-all of them obdurate-are apt to be less optimistic that current trends can be altered for long. Thus firms tend to see change as a gradual process. Those in the financial community, by contrast, live in a world of rapid flux in which new types of contracts can be introduced 
almost as soon as conceived, and in which a "deal" can almost always be struck between conflicting valuations and interests. ${ }^{22}$ No wonder expectations differ.

The household sector appears to be constrained to the most realistic set of expectations. Households experience at first hand the wage, price, and credit dimensions of the marketplace already described. However, no stock market surge can suddenly jump the implied multiple on the ordinary household's income. No easing of credit will enable the household to borrow unsecured a large multiple of its income. Most important, in financial institutions and large businesses the assets people manage are not their own; serious mistakes may mean loss of authority or job, but not capital. When households make mistakes, they incur the consequences of essentially unlimited liability.

Individuals in our society have multiple roles, often with conflicting allegiances and objectives. Within each sector, and within the units in each sector, there occurs a kind of financial diversification of which research has taken little notice. In recent years, for example, the household sector has accumulated enormous debts to acquire tangible assets (mainly homes, but not equity securities ). At the same time, however, households have also acquired massive quantities of short-term, fixed-rate liquid assets, which at most times yielded after-tax returns well below the rate of inflation. Conceivably there were two distinct groups of households, but anecdotal evidence and the sheer mass of funds involved argue strongly to the contrary. Were these households foolish or uninformed? Neither is likely; the evidence is clear that shifts of yield differentials among the liquid assets produced large investment shifts. A possible rationalization is that the acquisition of illiquid assets (homes) with inflexible payment schedules (mortgages) is properly matched with an enlarged and inelastic precautionary demand for liquid assets. But if so, predicting the macroeconomic responses of the household sector takes on dimensions to which most forecasters have not paid much attention.

The ambivalence in expectations about the interest rate is even more profound and puzzling within the business sector. With respect to the maturity distribution of corporate borrowing, one may observe a paradox that holds to a quite useful approximation: in herd-like fashion,

22. Perhaps that is why grossly premature reports of peace in Vietnam, Iran's release of the hostages, and similar implausible rumors have such large echoes in financial markets. 
corporations tend to borrow most heavily at the maturity with the highest interest rate. When short-term rates are low relative to long-term rates, corporations expect both rates to rise; when short-term rates are high, they expect both to fall. Such expectations are in accord with the empirical history of covariance in short-term and long-term rates (although nothing in expectations theory relates the slope of the yield curve to anticipations of change in long rates).

Because short-term rates have been low mainly during and immediately after recessions, firms have had only a few brief spans since the early 1960 s that they considered propitious for the issuance of long-term bonds. Most of the time they were deferring long-term finance while waiting for interest rates to peak, with the intent of issuing long-term bonds at the recession trough expected to follow sometime after the peak. But because the recessions and peaks in interest rates chronically took longer than expected to arrive and because the long-range trend of interest rates was strongly upward, considerably higher rates had to be paid after the peak than if the borrowing had been done earlier. (There was also some tendency to rush in prematurely after the peak, before bond yields had the full opportunity to decline.) That this sort of mistake was made by some firms some of the time is not surprising, but it is remarkable that it has been so persistently repeated in the aggregate.

The phenomenon is illustrated in figure 4 for the 1962-80 period when the behavior I am describing was most marked, using aggregate data for nonfinancial corporations. The dashed line is a measure of the corporation's gain or loss with respect to the interest rate from deferring issuance of long-term bonds. In general this measure (whose construction is described in detail below) would rise if interest rates were about to fall: in such circumstances it would pay the issuer to wait. Conversely, when rates are on the way up, the measure declines: now postponement of an issue will be costly. The solid line is the actual proportion of net corporate external financing that in fact took the form of bonds. ${ }^{23}$

The figure shows a predominance of "wrong" decisions. Long spans of time occurred when corporations would have been well advised to float bonds heavily but failed to do so; and there were other times, particularly

23. Total external financing is net funds raised through corporate bonds, bank loans (not elsewhere classified), banker's acceptances, and commercial paper, as defined in the Federal Reserve's flow-of-funds accounts. The data used in the figure are four-quarter moving averages centered on the second observation. 
Figure 4. Gain and Loss from Deferring Bond Issuance Compared with Proportion of Bond Issuance in Total External Borrowing, Nonfinancial Corporations, 1962:1-1979:4
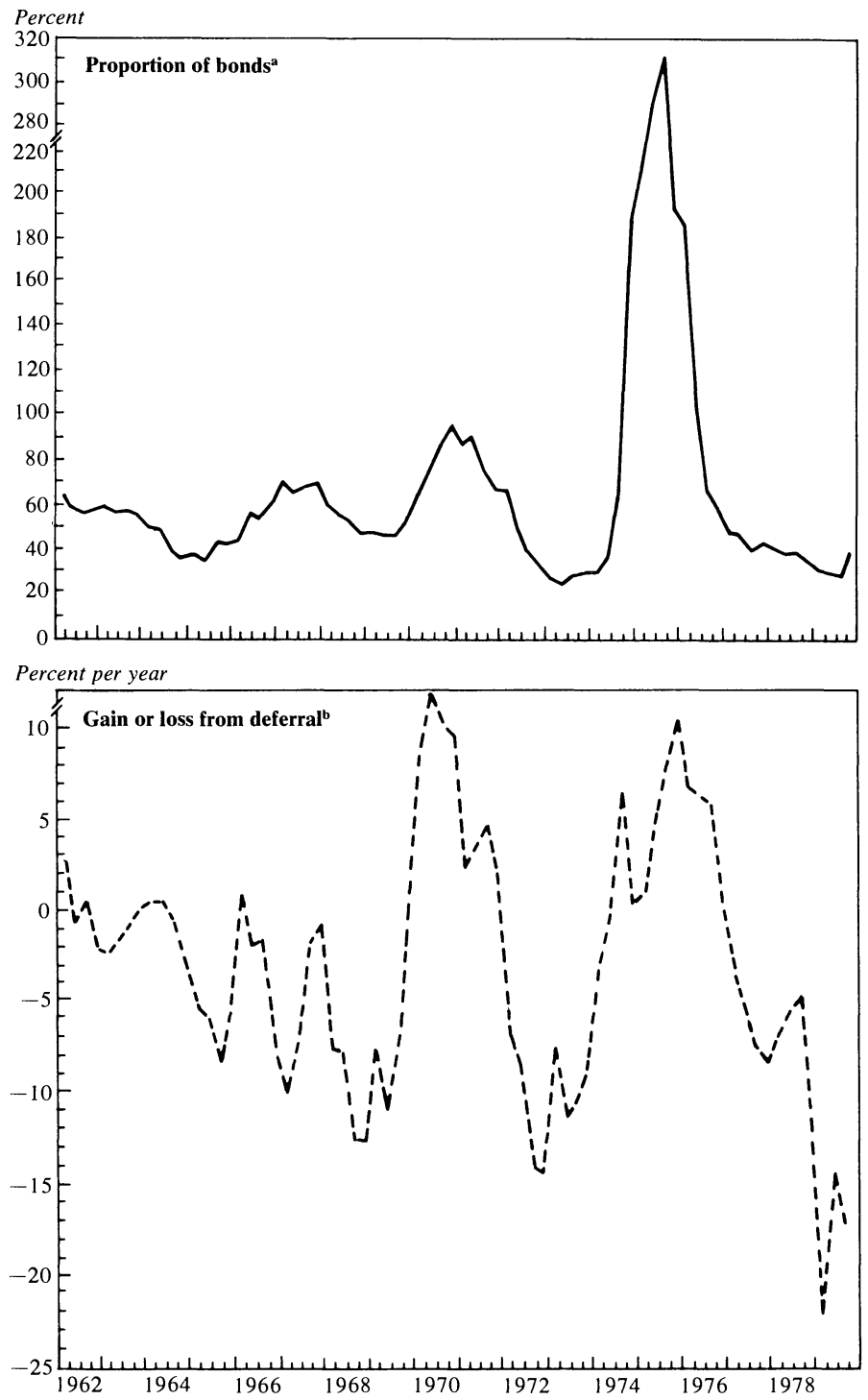

Source: Board of Governors of the Federal Reserve System.

a. External borrowing includes corporate bonds, bank loans, n.e.c., bankers' acceptances and commercial paper. The series is a four-quarter moving average centered on the second observation. Data are from flow-of-funds accounts.

b. Calculated as the difference between the one-year holding period yield on twenty-year constant maturity Treasury bonds and the average yield on three-month Treasury bills. Data are monthly averages of daily yields and are taken from the Federal Reserve Bulletin, various issues. 
in the 1970s, when those firms jumped prematurely into the fire. This impression is confirmed by a regression on the (unsmoothed) data for the period 1962:1 through 1979:3, explaining the proportion of net bonds in corporate external financing by the gain from deferral. The regression shows the "wrong" sign on deferral, with a $t$-statistic of 3.8. ${ }^{24}$

The measure of gain or loss through deferral requires explanation. It is the difference between a long-term and a short-term rate. The longterm rate is the yield on twenty-year Treasury bonds held for one year forward from the date shown. The one-year span is a crude proxy for the common corporate attitude of "wait till after rates have peaked." The holding-period yield is, of course, also the cost to the issuer. The shortterm rate is the average three-month Treasury bill rate over the same oneyear span, ${ }^{25}$ the cost of the alternative-to borrow for the short-term. The difference between these two rates, then, is a measure of the gain or loss the issuer incurred by deferring long-term borrowing for a year.

The peculiar corporate response pattern appears to reflect a conflict within large firms. For a decade or more, virtually without exception, the many internal corporate plans to which I have been privileged to have access (usually through verbal description by the chief financial officer or higher) have extrapolated, as mentioned above, a moving average of recent inflation rates of costs and product prices. Most of the time, however, the interest rates assumed in the plan were below the current longterm rate and less than the expected inflation rate. Sometimes the inflation and rate assumptions came from different parts of the firm, having been melded into the corporate plan at the highest executive levels. Not too infrequently, however, the conflicting assumptions came from one group or even individual (including the economists). On the whole, it might be said, the forecasts of the production side tended to reflect the current, usually inflation-biased, state of mind of the production community. The financial forecast reflected the disinflation bias of the financial community. How then should one summarize the actual state of inflationary expectations of corporations? How can that multidimensional sum fit into an aggregate of the total of such expectations of the society (or world) as a whole?

24. The actual regression equation is

$$
\begin{gathered}
\text { Bond proportion }=0.81+4.4 \text { (gain from deferral), } \\
(3.8) \\
\bar{R}^{2}=0.16 \text {; Durbin-Watson }=1.5 .
\end{gathered}
$$

25. Actually this is a five-quarter moving average weighted $1,2,2,2,1$. 
The most interesting case of schizoid expectations comes from the financial community, although here my evidence is unfortunately entirely anecdotal. That financial managers in their professional capacities have had a more optimistic outlook than the public on security prices is surely attested by the fact that institutions have continued to acquire massive amounts of bonds in the face of virtually continual declines in real and all too often also nominal values. Meanwhile the public has clearly shifted its investment mix toward increasing its borrowings and its real estate assets, producing palpably superior investment performance.

In the latter 1960s when the stock market was in the grip of speculative fever, this discrepancy was far less pronounced. At that time, investment managers themselves bought heavily for their personal account the same securities they were acquiring in their fiduciary capacities. They and their customers were going to become rich together.

By the latter 1970s this pattern had changed radically. Among my many acquaintances of "money managers," the majority have been emphasizing for their personal account real estate and collectibles, commodities, and futures, while as fiduciaries they are continuing to profess sincerely their confidence and in most cases are investing actively in securities. As already mentioned, these individuals as a group are highly educated, well informed, intelligent, and responsible.

I would venture to assert that a similar discrepancy between personal conduct and professional opinion prevails among high-level government policymakers.

In sum, the prevailing economic expectations of society are a rather heterogeneous lot that is not easily aggregated. Possibly the potency of credit crunches and other violent shocks lies in their capacity for galvanizing everyone's expectations in the same direction. Without such cataclysms, however, the market clearly shows nothing remotely approaching the unanimity concerning the "correct" model of the economy stipulated by the rational expectations approach. That approach has provided a useful reminder that expected governmental actions are routinely taken into account in people's planning - although in truth the public and politicians have always spoken the "prose" of anticipating each other's reactions, leaving mostly the economists in need of the reminder. Uncertainty and differences of opinion continue and hopefully always will prevail in the marketplace, both with respect to the nature of the "true" economic and political models of our time and thus also with re- 
spect to what (probably zig-zag) course government policy is likely to take and its consequences. As a result, most noneconomists (and wise economists, too) find it prudent to diversify their economic theory as well as their securities portfolios. The general acceptance since the mid1960 s of the view that recessions can be substantially mitigated and tamed places the public and policymakers in a kind of cobweb and gaming relation to one another.

That relation is further complicated by the mutual realization that "unacceptable" outcomes will trigger changes in the rules. The notion that the public would ever voluntarily concur in a single-minded view of the economy has the same deep totalitarian roots as the New Left slogan "power to the people," which asserts that an amorphous crowd can develop coherent policies without any kind of organizational structure. Those who in fact prevail in such unstructured "town meetings" are the demagogues best able to incite the crowd and intimidate their opponents. Such ideas are attractive only to those who believe that they are in sole possession of the truth and would therefore hold exclusive power in a society in which such truth was enshrined as the national religion.

\section{In Defense of Credit Crunches}

I have tried to describe here a Weltanschauung, an approach that is widely and I believe justly regarded as having foretold, with reasonable timing and amplitude on a lead time of six to eighteen months, most of the major fluctuations in business and interest rates and relevant institutional changes in finance since early 1964 when I joined the investment banking community. The technique, if it deserves to be dignified with that label, has been to identify the relevant private and official "crowds" and their current reaction patterns and to use economic theory to assess the consequences of the interactions as the results reinforced or conflicted with one another or with aggregate constraints.

At the cyclical level, the chief lesson has been that rationing by interest rate (so-called gradualism) will not stop business expansions. Indeed, a kind of "immune" reaction has developed to rising rates in which the expectation of recession that those rises engender among government officials and financial institutions sets off credit expansion mechanisms 
that prevent recession. Only credit crunches, conceptually analogous to sudden gasoline lines, trigger business downturns.

After each crunch, however, steps have been taken at private and official levels intended to prevent even any expectation of its recurrence. Of all these steps-and this has been implicit but not explicitly stated in the preceding discussion - the shift to an $\mathbf{M}_{1}$-dominated monetary policy has been the most permissive. Since the United States has subscribed to a monetary aggregates policy, the trend of monetary growth, inflation, interest rates-and unemployment-has been upward. Others can describe better the pitfalls of assuming that variables endogenous in the economy will continue their previous roles and relations once they are made control variables-eloquently summarized in Goodhart's law: "Any statistical regularity will tend to collapse once pressure is placed upon it for control purposes. ${ }^{26}$ I can testify that to all except perhaps the most indigent of the economic actors, the money stock - in contrast to oil or credit-is a meaningless abstraction. No individuals of even moderate means, or firms other than those at the edge of bankruptcy, base their spending plans on $\mathrm{M}_{1}$ balances, and no bank of any consequence looks to demand deposits as an important source of funds. If there were to be promulgated a permanent zero money-growth target, hardly anyone would regard himself as constrained. That is why there is so little political conflict about the concept and setting of monetary growth standards (and also why central banks are so fond of them). But the record as described here would suggest that only policy constraints that carry a direct understandable message (Uncle Sam Wants You!) will be effective.

In sum, credit crunches caused by regulatory constraints on the financial markets have played a constructive role in precipitating cyclical downturns ahead of more serious endogenous bankruptcy crises that otherwise would have ensued, and before the high inflation rates characteristic of business cycle peaks could become deeply embedded. The constructive effects would have been greater if firm, well-understood, and vigorously policed limits on interest rates been kept in place rather than removed after each collision. Market participants then would have learned restraint rather than defiance. The usefulness of rigid limits is in creating a de facto community of private and official interest in avoiding

26. Letter to the author from Charles A. E. Goodhart, chief adviser on monetary policy, Bank of England, September 17, 1980. A narrower variant that has been suggested is: "Any variable the central bank chooses to control automatically becomes irrelevant." 
a collision with the rules, contrasted with the game of "chicken" being played now. To be sure, all manmade constraints, like the pegged gold price, fixed exchange rates, or a monetary rule, tend to be relaxed under pressure, but not necessarily easily or predictably, at least not the first time. The time to save the Regulation $Q$ type of constraints was in the late 1960s and early 1970s when they were set low and the public was still reluctant to sanction higher interest rates - showing greater foresight than the economists.

A policy of limits would not compete with but rather would complement more traditional monetary policy approaches. Without the Federal Reserve's efforts at monetary restriction, the flashpoints represented by the various ceilings on interest rates would have been reached much later when inflationary pressures were even more intense. But had the ceilings been taken more seriously, the Federal Reserve's policies would have had greater impact long before any crunch. Even today, there would be more "bite" from a pronouncement by the chairman of the Federal Reserve that under certain conditions he would reinstitute ex post facto loan ceilings than from his promulgation of low $\mathbf{M}_{1}$ targets, which enjoy little credibility and which will have little anti-inflationary impact if achieved.

By no means do I want to suggest that the fundamental cause of the inflation of the 1970s was a faulty choice of monetary policy instruments. Some considerable inflation would have occurred in any event, but it might have been less - and the danger of a runaway inflation less - if the old regulatory restraints had been modified rather than abandoned completely. The fundamental causes of the inflation are noneconomic, I believe, and are outside the scope of this discussion. They involve the changes in the internal and external relations of the United States after World War II as it gained and then lost world hegemony. Now an introverted economy heavily oriented toward providing domestic amenities is compelled, by its loss of geopolitical dominance, to give up a significant margin of its standard of living. This is the cost of building military preparedness, producing the additional exports to pay the higher price of oil imports, developing extensive energy substitutes, subsidizing or replacing mass production industries doomed by foreign competition, and maintaining the relatively restrictive macroeconomic policies necessary to protect the international value of the dollar, whose stability is vital to our external political influence and to keeping down the oil price. Inflation is a standard historical response for societies forced to reduce their economic aspirations-and is useful up to a point in averting di- 
visive internal strife about how the new burdens are to be distributed. But the lack of a social compact for burden sharing is a reason for strengthening rather than weakening the institutional restraints on inflation that may remain.

It is presumably impossible to restore most of the financial constraints that have already been swept away. This is not the place for nor do I have a full agenda of substitutes to offer. The list would include marginal capital requirements on banks, outlawing floating-rate credit contracts, punitive margin requirements on futures transactions, and liberal but rigid (not discretionary) down payment and maturity limits on mortgage and installment credit. As with a monetary aggregates policy, the rules would have to be continually monitored and adapted to keep abreast of institutional changes designed to circumvent them. ${ }^{27}$

How impractical! But meanwhile, with most legally institutionalized fuses in the credit process having been removed, inflation will eventually run on until some new regulatory mandate must be invoked to create a bottleneck, or until financial stress builds to a new peak intensity that cripples a hitherto untested vital organ.

The freeing of financial markets to pursue their casino instincts heightens the odds of such crises. With few bounds left on short-run price change, floating rates in the key banking sector, new futures markets, large international crowds of participants - and with a much more unstable "outside" world providing continual reminders of the futility of longer-range plans-bizarre financial behavior is to be expected. Because, unlike a casino, the financial markets are inextricably interlinked with the world outside, the real economy pays the price.

27. Growth limits for certain types of credit (a la March 14) may also have some promise. On the other hand, limits on total credit would provoke lenders to cease making socially desirable loans (including, perhaps, Treasury security purchases) in the effort to force abrogation of the new regulations. Reserve requirements against assets rather than liabilities are attractive in principle, but may fail in practice. Individual banks and their clients would continue to plan as they do now on the basis that reserves will always be available at a price. Observably, wide fluctuations and high interest rates are needed to contain the growth of $\mathbf{M}_{1}$, for which, as pointed out earlier, there are many effective substitutes. Credit does not have such substitutes, so that rates under an asset reserve regime might soar to truly astronomical levels. Although a single such experience might well make everyone more cautious in the future, it seems unreasonable to expect the Federal Reserve to remain tough if necessitous borrowers (including the Treasury) were threatening to drive interest rates quantum distances beyond the spring 1980 peaks. 


\section{Comments and Discussion}

Benjamin M. Friedman: Albert Wojnilower's paper is both stimulating and challenging. The paper asserts a number of fairly strong and not widely held hypotheses and then proceeds to recount the history of the postwar U.S. business cycles in light of these hypotheses. The burden of the paper, in brief, is to show that it is possible to make a sensible story out of reinterpreting - or, for those who may have been sympathetic all along, interpreting - the major business cycle peaks in the context of these hypotheses.

This paper is also appealing in several other respects. The history is marvelously told here, and the narrative is rich in subtle observations and by-the-way insights. It makes fine reading in ways that go beyond the purely economic issues in question.

In addition, some of the hypotheses advanced in the paper provide a refreshing contrast to alternative hypotheses that lately have become more prevalent in the macroeconomics literature, a key objective of which often seems to be to make readers feel inferior as they realize they are personally incapable of analyzing events with the level of understanding assumed in behalf of the representative worker or consumer. Such one-upmanship is comfortingly absent from the Wojnilower paper, from which readers instead come away secure in the belief that, despite their own inadequacies, they may still be able to assess the world more sensibly than the actors portrayed in the paper.

I begin my comments by stating, somewhat more formally than Wojnilower, what I think are the paper's six major substantive hypotheses. I then assess the evidence offered in the paper in support of them. The six logically fall into two categories: three propositions directly describing 
the behavior of agents in the market economy, and three propositions drawing out implications that follow from that behavior.

The first of Wojnilower's behavioral propositions concerns the demand for credit and its role in determining the economy's aggregate demand for goods and services. The proposition is that the demand for credit is not merely insensitive to interest rates but, more important, effectively unbounded at all plausible interest rate levels; and further, that much or all of this credit demand, if realized or accommodated, is then used to finance real spending. The important issue here is not merely one of rate insensitivity, but instead the potential unboundedness of credit demand. To be specific, on a diagram with an interest rate on the vertical axis and a quantity on the horizontal axis, the idea is not simply that the credit demand curve is nearly vertical but also that it lies far to the right of the associated credit supply curve at any interest rate relevant for applied analysis.

The second behavioral proposition, on the role of money, is that what matters for real spending is not just deposits held but potential access to deposits through the credit market. Hence the credit market, rather than the money market, is what is genuinely important in determining spending.

The third behavioral proposition, on portfolio behavior more narrowly construed, is that there has been a qualitative change in the behavior of both borrowers and lenders as a consequence of the proliferation of loan arrangements with a floating rate. The point here is not just that something is quantitatively different, in a way that could easily be represented by the shifting of a schedule (or even two), but rather that the relevant risk-averse portfolio behavior is now somehow solved in a qualitatively different way.

The combination of these three behavioral hypotheses leads in turn to three potentially important implications. The first is that there exists no equilibrium for the economic system, even in the loosest sense of an interior solution, so that the economy's position is determined by a corner solution in which the effective constraint is a finite and volatile supply of credit. The true story of the business cycle peak, therefore, is one of availability effects rather than interest rate effects, and of the credit market rather than the money market. Second, the process of removing credit market barriers imposed by financial market regulation, and analogous market imperfections, only renders yet more exaggerated the instability of the economic system which is, in effect, searching for the nearest corner solution. Third, a monetary policy based on monetary aggregate targets 
rather than credit aggregates, and especially on the more narrowly based monetary aggregates, is irrelevant at best and more likely counterproductive.

Much of the basic thrust of this line of argument is at least familiar, and the events of the 1970s in particular have given it a renewed plausibility. Hence I am inclined to be sympathetic at least to significant parts of the analysis. In assessing the contribution of the paper, however, it is necessary to consider the evidence that it offers in support of these propositions and to evaluate this evidence both on its own merits and in relation to evidence offered elsewhere.

The main evidence provided here is a somewhat loosely told chronological account of the postwar U.S. business cycle peaks. Its main point of emphasis is the fact that, as most people know, credit quantity measures and economic activity measures move together over the cycle. I have recently worked on this subject and have learned that it is virtually impossible to show that there is any more stability in the money-income relation than there is in the credit-income relation in the United States. It would be overstating the case to claim that the credit-income relation is the more stable of the two, but neither is it any less stable than the moneyincome relation, regardless of the specific methodology used to analyze the data.

Although much of Wojnilower's chronological account therefore focuses on this covariation of credit activity and real spending activity, the evidence presented in the paper is not adequate to make a persuasive case in behalf of the hypotheses being advanced. The problem here is not (at least I hope it is not) simply a matter of economists being so ingrained in the ethos of conventional time-series data analysis that they are unprepared to accept any other kind of evidence. For many economic phenomena-and the credit market is probably one of them-there is no doubt much valuable information that cannot be obtained from the available time-series data. Under such circumstances a researcher might sensibly seek an observer to interview as many transactors and potential transactors as possible during the course of a business cycle, and if possible then to repeat the process for the next business cycle, and so on. In many respects Wojnilower himself appears to have been just such an observer, ideally positioned to interview a large number and wide variety of the many people whose actions and attitudes collectively comprise the credit market. In principle, the reports from such an observer ought to contain 
valuable information that economists should be able to use in two ways: to provide evidence about economic behavior directly, and to generate suggestions of new ways to investigate the time-series data themselves.

From the perspective of its ability to support direct inferences about economic behavior, the principal problem in the evidence presented in Wojnilower's paper is that cause and effect are not well distinguished. The covariation between credit phenomena and real spending is a fact, and the paper documents it well enough at a descriptive level. Nonetheless, at the very least a much closer analysis of the chronology would be necessary to make a persuasive case that the supply side of the credit market has been the underlying cause of most or all of the major U.S. business cycle peaks. The chronology in the paper is, in too many cases, equally consistent with a reading in which credit supply has simply accommodated a volatile credit demand, determined in turn by independent movements of real spending that themselves remain unexplained. Sorting out causality in economics is difficult, but at least some progress along these lines would be necessary to support satisfactorily the hypotheses presented here.

In addition, Wojnilower's evidence is inadequate to distinguish interest rate effects from availability effects. In a number of instances, for example, the story told begins when, for some unexplained reason, interest rates have moved. The movement of interest rates then changed people's expectations of the future. The revision of expectations in turn changed the attitudes of lenders in the credit market, thereby shifting inward the vertical supply constraint so that the economy hit a corner solution. It is possible that this chain of events corresponded to the historical experience, but distinguishing between this story based on a supposedly essential availability effect and a corresponding rate-effect story is too difficult a burden to be borne by the evidence introduced here.

Hence while the propositions advanced in this paper have some substantial appeal, the evidence offered in their behalf falls short of making a persuasive case that they are true.

What about the relation between this evidence and that reported elsewhere? A problem which the paper never acknowledges is that other researchers, who have also sought evidence (of a more direct kind) to document the influence of quantity rationing effects on the business cycle, have been largely unsuccessful. As one example that may be pertinent 
here, in a paper several years ago I tested a hypothesis about the role of interest rate ceilings and their relation to loan rationing at commercial banks that was very similar to a key element in the story told by Wojnilower; my findings, however, were largely negative. An additional problem that proponents of hypotheses like those in the paper must face squarely is that there appears to be so much positive evidence in support of competing hypotheses. Why is it that equilibrium stories of the credit markets - that is, accounts of the determination of interest rates by the equation of a well-behaved demand and a well-behaved supply, or even by an arbitrage relation of some kind-seem to fit the data so well? Why is it that the more familiar stories of financial influences on the business cycle, which emphasize price (interest rate) and substitution effects, also seem to fit the data reasonably well?

The difficulty, therefore, is twofold. Researchers who have looked for evidence in support of availability hypotheses have failed to find it, while those who have sought evidence in support of competing hypotheses seem at first glance to have been relatively successful. What would be needed to render convincing the propositions advanced in the Wojnilower paper is some argument to the effect that most evidence found supporting other hypotheses was somehow misconstrued, and that what appeared to be price or interest rate effects were really quantity effects in disguiseperhaps because there is something inherently unmeasurable about quantity effects that consistently leads other variables to stand proxy for them. A similar argument that might reconcile the hypotheses about the role of credit with the evidence on the role of money could perhaps exploit the balance sheet constraint across assets and liabilities to show that what looked like evidence pertaining to money in reality pertained to credit. Wojnilower does not offer such arguments, but something along these lines would be necessary for his case to be compelling.

In sum, Albert Wojnilower's paper advances a number of plausible, interesting and, in some respects, even appealing hypotheses. Moreover, these are potentially important hypotheses because, if they are correct, they have strong implications for both monetary policy and financial market regulation. Nevertheless, the evidence adduced in favor of these hypotheses is not persuasive. Hence the real value of the paper is likely to be to point toward directions for future research. In this respect Wojnilower's work would be the more valuable if he could provide more help 
in suggesting ways in which economists who do rely on more direct kinds of evidence could find results there that might support the propositions the paper advances.

Franco Modigliani: Wojnilower's paper is both fascinating and refreshing. It is fascinating because, as an acute observer of the financial markets, he provides many valuable and novel insights on the way in which monetary policy works through the credit markets, at least as seen by the insiders. It is refreshing because, at a time when everybody seems to be joining in the chorus in favor of deregulation and in condemnation of credit crunches, he takes an almost mischievous pleasure in building his case against deregulation and in pointing to credit crunches as the only mechanism that really works. His view, in a nutshell, is that expansion and contraction are basically brought about by the rise and ebb in the availability of credit, and that once credit starts expanding, only a credit crunch can effectively bring a halt to it.

I find the author's emphasis on the role of credit particularly interesting because it agrees with and reinforces conclusions $I$ have reached in research currently under way on the nature of the monetary mechanism. This research leads to a rejection of the standard view that nominal income is controlled only through the money supply. It supports, instead, the conclusion that income can be controlled by restraining any one of a large number of nominal aggregates, including not only broader concepts of money or liquid nominal assets, but also a variety of credit aggregates. Furthermore, in a deterministic world in which the monetary authorities knew all the relevant behavioral relations, whichever of these aggregates were chosen as a target of control would be totally immaterial. There would, in fact, be a one-on-one relation between each aggregate and nominal income and, therefore, controlling any one of them would determine both nominal income and all the other aggregates endogenously, including the money supply if that were not the target. In a world of uncertainty the degree of control over nominal income would be different depending on the aggregate chosen as the target and would be affected, in particular, by the financial structure of the economy, including the extent and nature of regulation. Research also suggests that, under certain conditions, credit may be a particularly suitable target. This is presumably why it has been so used in a number of countries. Even in the United States, preliminary research such as that by Benjamin 
Friedman suggests that the relation between nominal income and broad credit aggregates is as stable, and perhaps even more stable, than that between income and the conventional $\mathbf{M}_{1}$ or the monetary base.

Wojnilower goes beyond calling attention to the role of credit as a determinant of economic activity. He also emphasizes in his view that what matters is the availability of credit, not its price. The demand is seen as being very inelastic to price; and if price matters at all it is more likely to be through its effect on supply or through psychological effects.

This aspect of the analysis calls to mind one of the great debates of the fifties that centered on the so-called availability doctrine-whether it was appropriate to free interest rates from the straitjacket imposed during the World War II period. Those who opposed deregulation based their argument on the inelasticity of the demand. In essence they argued that, with an inelastic demand for credit, the containment of demand would have required a large rise in interest rates with a devastating impact on bondholders and destabilizing effects on financial markets. Those who favored deregulation were quite prepared to accept the inelastic demand for credit but argued that the required increase in interest rates would have been small-for even a modest rise would have been sufficient to dissuade intermediaries from liquidating their portfolios of government securities because of the capital loss that they would have had to show. Hindsight suggests that the availability mechanism may have played some role at the time, but at best it was limited both in magnitude and in duration.

Wojnilower replaces the above effect of interest rates on the supply of credit and the corresponding capital losses with a variety of other mechanisms. Besides the general notion of availability constraints eventually working on the supply side, around peaks a psychological mechanism becomes important in the behavior of borrowers. At such times, the expansion of credit comes to an end not because potential borrowers find that acquiring assets is undesirable as a result of the higher carrying cost, but rather because they think that other people would want to borrow less and therefore there will be problems ahead. As a result, both borrowers and lenders pull in their horns.

But aside from these "crunch" interruptions in the expansion of credit, Wojnilower provides us with no clear explanation of what limits its supply. Indeed, one has the impression that, besides credit crunches, nothing limits credit expansions except the will of the lenders. 
In my analysis mentioned above, credit is limited either directly by the central bank (for example, through reserve requirements against credit) or by control of some other aggregate, such as $\mathbf{M}_{1}$ or the monetary base, as generally has been the case in the United States. With limits on $\mathbf{M}_{1}$ or the base, it is hard to see how credit, and hence economic activity, can expand without bounds. At some point the expansion must be limited by the lack of reserves. Wojnilower does not mention such a limit, and one may suspect that he, too, suffers to some extent from a myopia that is commonly attributed to bankers. All bankers think they can expand without limits provided, of course, they can attract liabilities; and they may think that liabilities can always be attracted by offering an appropriate price or other services. But what one bank gains must be at the expense of others. The system as a whole cannot gain more reserves than there are.

At times Wojnilower seems to suggest that once credit has been extended by the banking system, the central bank is forced to accommodate it by supplying reserves in order to avoid a crisis. If this were true, the base itself would be endogenous and no limit would be placed on the expansion of credit and nominal income. There may be some truth to this story, in part because the central bank is, after all, a lender of last resort. In addition, Wojnilower takes the view, which I partly share, that the Federal Reserve tends to act in the best interests of the financial community, particularly banks, and might be willing to accommodate rather than face the system with the consequences of disobedience. It also is true that the relation between credit and the monetary base cannot be regarded as a rigid one. Intermediaries can, and have, devised a number of base-saving devices. However, much of this base-saving requires financial innovations which, in turn, take time. On the whole, therefore, I think that Wojnilower overstates the ability of the credit system to run away with the ball. At least in the short run, the limitations imposed by the monetary base are real, even if somewhat elastic.

Much of Wojnilower's paper is devoted to a history of the evolution of the U.S. financial system and its relation to monetary policy. The basic thread that runs through this account is that past credit crunches led to deregulation which, on the whole, made the system even more difficult to control, thus requiring further crunches that led to more deregulation, and so on. The crunches, in his view, at least had the merit that they ac- 
complished what they were intended to do. But Wojnilower has little sympathy for deregulation: it increases uncertainty, at least in the short run, because it changes the rules of the game; and it has the effect of placing increasing emphasis on the price and less on the availability of credit as the critical variable of the system. This shift is, in his opinion, a move in the wrong direction from the standpoint of the controllability of the system. I tend to agree with his assessment of the relation between deregulation and controllability of the system, though I am not prepared to support him in his conclusion that, therefore, all deregulation is bad.

Actually, the proposition that certain types of market imperfections may, under appropriate conditions, facilitate the task of the central bank in controlling demand fluctuations is not entirely novel. It has been shown in a number of cases (including my own contribution) that when the variable controlled is money (or, possibly, interest rates), then insofar as credit can be rationed by devices other than price, such as credit rationing, the stabilization of income in the face of fluctuations in aggregate demand can be achieved with smaller fluctuations in market interest rates and, therefore, also with smaller countercyclical changes in money supply. ${ }^{1}$ The rationing may be limited to some sectors and can be achieved by a variety of controls. For instance, mortgages for home buyers have been rationed at times of heavy demand for credit by placing ceilings on the deposit rates of the savings and loan institutions, thus impairing their ability to bid for funds on behalf of that market. This means that the remaining demanders had more funds available to them, and thus the market could be cleared at a lower rate. Given sufficient time, alternative channels can and have been developed; but in the short run it has proven an effective way of shutting off some potential borrowers from bidding for funds, therefore holding down the rise in major market rates.

Although I concur that rationing credit by availability rather than by price has the desirable effect of reducing the fluctuations of interest rates, and hence of lowering prices of certain assets, and probably of making the life of the central bank easier, I would hesitate to share Wojnilower's opposition to all decontrol. Clearly, the effects in terms of better allocation of resources or elimination of oligopolistic rents need to be taken

1. Franco Modigliani, "The Monetary Mechanism and Its Interaction with Real Phenomena," Review of Economics and Statistics, vol. 45, no. 1, pt. 2 (February 1963, supplement), pp. 79-107. 
into account. The only inference that I would draw is that not all decontrol measures are good ipso facto and that each measure should be scrutinized and judged on its merits.

One consideration that leads me to emphasize the need for this scrutiny is that my analysis suggests the presumed undesirable effects of deregulation on the controllability of the system tend to be present only when monetary control is through money or the base. But if, as is true in a number of countries, the aggregate controlled is a broad measure of credit—say total credit of all depository intermediaries-interest rate ceilings and similar regulations tend to reduce the effectiveness of controls, while vigorous competition in financial markets tends to improve it.

The common sense of this proposition can best be seen by an illustration. Suppose the central bank decided that, for some reason, it was appropriate to restrict credit and, accordingly, through its direct control reduced the amount of credit that banks are allowed to extend. Suppose now that ceilings prevent banks from raising the loan rate or the deposit rate to market clearing levels. It would then be in the interest of both borrowers and lenders to bypass the intermediaries and contract at freemarket rates above the bank rate, because borrowers can, thereby, secure more credit and lenders can obtain a better return. In short, there would be an increase in disintermediation, with the result that the reduced lending by the banking system may be largely offset by additional lending outside it. On the other hand, with competitive markets, the loan rate would rise to clear the market, while competition between banks would tend to result in a commensurate rise in the deposit rate. There would then be no incentive to increased disintermediation, and the intended credit contraction would be fully effective.

An interesting implication of this illustration is that the workings of the monetary mechanism are quite different depending on whether control focuses on the liability instruments with which intermediaries secure funds or on bank credit extended with these funds. One may suspect that many shortcomings in monetary analysis and policy derive from mixing up the two alternatives. It would be ironic in this context if the attack by Wojnilower and the "New York view" against deregulation were to make headway just at a time when policy may be starting to lean toward control of credit aggregates!

I am sure the careful reader of this paper will appreciate that its real contribution does not lie in the author's provocative attacks on deregula- 
tion, but rather in his analysis of its operation, as seen by a thoughtful participant in the financial markets. The economy clearly is still in a period of transition, and as alternative forms of monetary controls continue to be considered, this kind of analysis and thoughtful account of events will be extremely valuable.

\section{General Discussion}

Several participants supported essential features of Wojnilower's analysis. John Kareken suggested that the changing distribution of expectations is an essential feature of business cycle dynamics, especially around turning points when the normally dispersed distribution collapses toward unanimity. He also agreed with the treatment of institutional change-including what serves as money - as an endogenous response to policy and financial market developments. Dwight Jaffee likened the analysis to Irving Fisher's theory of business cyclical peaks: as the economy approaches the peak, firms' expectations of nominal returns outrun the rise in nominal interest rates. Those firms increase their demand for credit until the central bank somehow limits its credit availability; then expectations are disappointed and the contraction begins.

The role of interest rates-as opposed to restricted availability and credit crunches-in stabilization was discussed extensively. Robert Hall argued that real activity and credit demands were much more sensitive to interest rate variations than Wojnilower's model implied; however, policy had seldom allowed real interest rates to vary enough for stabilization purposes. Hall expressed surprise and dismay at Wojnilower's complete lack of confidence in unfettered private markets. Jaffee agreed that policymakers had historically not allowed interest rates to rise enough to level off a boom, relying on restricted credit availability instead. But he noted that real rates did rise substantially at the 1980 peak; he predicted that rates would fluctuate more in the future and real rates would be higher at peaks now that housing finance is integrated with the general capital market. Wojnilower noted that, although there might be some response of activity to interest rates, particularly in a sector such as housing, real rates would never be permitted to rise enough to head off a boom. Even if a large, but tolerable, rise in rates did bring down housing starts, that would not be enough to assure an economy-wide slowdown if credit were still 
available to other sectors. William Fellner reasoned that the interest rate mechanism has not been a stabilizing factor because real rates have generally been low or even negative. This situation has existed because uncertainty has dominated business borrowing demands while households have had to accept available low rates in order to maintain liquidity. Ralph Bryant observed that the growing openness of the economy, through which interest rates affected exchange rates and the real trade balance, increased the response of the economy to interest rates, but possibly not with the timing that stabilization required.

Some participants discussed the difficulty of testing Wojnilower's model empirically. Christopher Sims warned of major pitfalls in trying to infer the relation of financial variables to real cyclical activity. Because frictionless financial markets can respond promptly and strongly to disturbances while real activity is subject to frictions and inertia, any disturbancewhether from real, financial, or policy developments-can show up in financial market before it appears in real activity. Thus simple Grainger causal tests as well as informed study of unusual historical developments can be misleading. Sims concluded that the paper may assign too much importance to financial developments generating real developments in the economy. Wojnilower agreed that economic developments often originated in real disturbances, but argued that policy still confronts the task of mitigating rather than amplifying them through financial markets. Thomas Juster pointed out that Wojnilower's view of cycles defied testing with conventional time series methods because it presumes that dramatic changes characterize economic decisions around turning points. Jaffee noted that it is difficult to identify and model credit crunches because they represent disrupted markets in which lack of availability is not easily distinguished from lack of demand.

Panel participants expressed differing views on Wojnilower's call for more effective control of credit creation. Bryant argued that the increased internationalization of the U.S. credit market makes it more difficult to implement nonprice constraints. Wojnilower agreed, and added that the Federal Reserve's role as a lender of last resort for the international financial system weakens its ability to pursue domestic objectives. He believes that some control would eventually have to be extended to the foreign lending of U.S. banks. Robert Holland predicted that the recent evolution of financial markets toward interest rate equilibration would continue because it reflects society's dislike of arbitrarily drawn limits. He thought 
that only a debacle along the lines of 1929-33 in financial markets could reverse the trend and lead toward the kinds of constraints Wojnilower advocated. Charles Holt pointed out that if a system were dynamically unstable, intervention points would have to be established to control it.

Phillip Cagan argued that quantitative credit controls have never been very satisfactory but that there was a legitimate role for control over the monetary franchise in the form of reserve requirements on all kinds of money and money substitutes. Hall contended that policy should rely on changes in real interest rates to stabilize the economy, despite the fact that such variations might have to be large, in order to realize the efficiency gains from a free-market system. But Kareken responded that since the Federal Reserve and the Federal Deposit Insurance Corporation provide insurance to the banking system at prices that are independent of risk, there is no presumption of efficiency gains resulting from removal of quantitative restrictions. Wojnilower replied that the attempt to move toward a perfectly free market would result in such unacceptable fluctuations that the political system would not tolerate them, leading to controls that were worse than those that he was advocating. 